\title{
The impact of blockchain technology on business models - a taxonomy and archetypal patterns
}

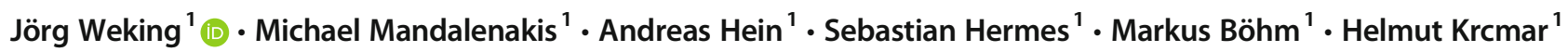

Received: 15 January 2019 / Accepted: 18 November 2019 / Published online: 23 December 2019

(C) The Author(s) 2019

\begin{abstract}
Blockchain technology enables new ways of organizing economic activities, reduces costs and time associated with intermediaries, and strengthens the trust in an ecosystem of actors. The impact of this seminal technology is reflected by an upcoming research stream and various firms that examine the potential uses of blockchain technology. While there are promising use cases of this new technology, research and practice are still in their infancy about altering existing and creating new business models. We develop a taxonomy of blockchain business models based on 99 blockchain ventures to explore the impact of blockchain technology on business models. As a result, we identify five archetypal patterns, which enhance our understanding of how blockchain technology affects existing and creates new business models. We propose to use these results to discover further patterns fueled by blockchain technology and illustrate how firms can use blockchain technology to innovate their business models.
\end{abstract}

Keywords Blockchain $\cdot$ Business model $\cdot$ Design science $\cdot$ Taxonomy $\cdot$ Pattern $\cdot$ Platform

JEL classification $\mathrm{O} 3$

\section{Introduction}

Blockchain is a contemporary technology with the potential to build a foundation for creating unprecedented business models (Iansiti and Lakhani 2017). Of particular interest are business models that remove intermediaries in an ecosystem of actors

Responsible Editor: Larry Shi

Jörg Weking

weking@in.tum.de

Michael Mandalenakis

michael.mandalenakis@tum.de

Andreas Hein

hein@in.tum.de

Sebastian Hermes

sebastian.hermes@in.tum.de

Markus Böhm

markus.boehm@in.tum.de

Helmut Krcmar

krcmar@in.tum.de

1 Technical University of Munich, Chair for Information Systems, Boltzmannstr. 3, 85748 Garching bei München, Germany and those that foster security over performance (Lacity 2018). This change in a ventures' business models adversely impacts several industries (Kshetri 2018; Wang and Kogan 2018). Existing blockchain solutions in the financial industry, for example, eliminate the need for reconciliation and intermediation and enable direct transactions between trading partners (Short 2018). In addition, blockchain technology enables its participants to continuously trace their assets and settle transactions autonomously while providing a secure model that is fault-tolerant, resilient, and permanently available. Upcoming blockchain solutions, such as VeriPart from Moog in the manufacturing industry, facilitate enhanced security and resilience features to increase trust in 3D-printed parts. Inspired by those firms and the expectation for added business value, an increasing number of organizations are actively considering blockchain technology to be a foundational technology (Lacity 2018; Iansiti and Lakhani 2017). In sum, blockchain technology helps authenticate traded goods, facilitate disintermediation, and improve operational efficiency, thereby influencing existing and creating new business models (Nowiński and Kozma 2017).

Whereas the impact of blockchain technology on business models is important (Lacity 2018), current research predominantly focuses on technological aspects (Nakamoto 2008; Wang and Kogan 2018; Eyal and Sirer 2018) and its 
application in practice (Kshetri 2018; Jun and Vasarhelyi 2017; Radanović and Likić 2018). Examples illustrate the transformation process (Ying et al. 2018; Y. Chen 2018) and indicate how blockchain technology can potentially alter processes and service provision within different industries. However, to the best of our knowledge, no empirical-based research exists regarding how blockchain technology can both change existing and build the foundation for new business models.

In addition to a lack of theoretical focus on the influence of blockchain technology on business models, blockchain companies still fail to deliver the promised business value. Firms lack an understanding of how blockchain technology can create business value for their respective business model (Lacity 2018). Furthermore, it remains unclear what business model patterns have proved to be already successful for this new foundation technology. Building on those shortcomings, this paper focuses on the following research questions:

\section{Research Question 1: How can blockchain business models be classified in a taxonomy? \\ Research Question 2: What are archetypal business mod- el patterns for blockchain technology?}

To address these questions, we use design science research to develop a taxonomy for blockchain business models and to extract archetypal patterns (Gregor and Hevner 2013). First, we establish a theoretical understanding by conducting a literature review (Webster and Watson 2002) of business models and blockchain technology. Next, we sample a broad database of 99 firms that utilize blockchain technology. We iteratively combine the empirical data with the results of the literature review to develop a business model taxonomy (Nickerson et al. 2013). The blockchain business model taxonomy follows the conceptual representation of business models (Massa et al. 2017). We end by evaluating the ending conditions of taxonomy development (Nickerson et al. 2013). Second, we perform a cluster analysis (Kaufman and Rousseeuw 2009; Struyf et al. 1997) of the blockchain business model taxonomy based on prior theoretical contributions and the database to derive archetypal patterns as reoccurring successful traits (Weking et al. 2018a). We conclude the cluster analysis by evaluating the resulting five patterns using Fisher's exact test (Fisher and Bennett 1990) to confirm that the patterns significantly differ from one another.

\section{Related work}

\section{Business models}

The concept of business models has gained increasing interest among scholars in recent years (Spieth et al. 2014;
Frankenberger et al. 2013; Foss and Saebi 2017; Hermes et al. 2019). A consensus is evolving to conceptualize business models as an overall description and architecture of how a firm creates, delivers, and captures value (Osterwalder et al. 2005; Shafer et al. 2005; Teece 2010). In this work, we build on the business model elements proposed by Wirtz et al. (2016): value proposition, value creation and delivery, and value capture. These elements prove to be reasonable for our research as they are used in similar ways by other taxonomies (Täuscher and Laudien 2017; Remané et al. 2017) and business model frameworks (Bocken et al. 2014; Wirtz et al. 2016).

Value proposition refers to the bundle of products and services that a firm offers, whereas value delivery relates to the identification of the target customer. Value creation describes the processes and activities, resources and capabilities, and their orchestration in the firm. Value capture explains how the firm makes money by illustrating revenue and cost structures (Frankenberger et al. 2014; Gassmann et al. 2017). Teece (2010) provided multiple examples of how business models differ based on their respective industry. While traditional firms are mainly concerned with producing physical products and optimizing supply chains, Internet-based firms operate digital services and strive to find the optimal price for information.

\section{Blockchain}

\section{Definition and Technical Foundation}

Because the development of blockchain is only in the initial stages, definitions are still emerging and no consistent definition has yet been adopted (Swan 2015). However, several authors agreed that decentralized ledger technology is key to the blockchain concept (Gomber et al. 2018; Du et al. 2019; Swan 2015). Swan (2015) described that the main idea of the blockchain is "that the decentralized transaction ledger functionality of the blockchain could be used to register, confirm, and transfer all manner of contracts and property."

Similarly, Gomber et al. (2018) stated that "the central technical innovation associated with blockchain is digital ledger technology, which is defined as the use of decentralized digital trust verification through encrypted digital signatures." Abstracting from a general definition, Christidis and Devetsikiotis (2016) proposed four key advantages of the blockchain: tolerance to node failure; single view of events; transparent, verifiable, predictable, and audible activities; and data ownership without a central authority. In general, blockchains record transactions by creating a chain of data blocks. Du et al. (2019) emphasized five IT artifacts of blockchain technology that support these transactions, which are outlined in Table 1. 
Table 1 IT Artifacts of Blockchain Technology

\begin{tabular}{|c|c|c|}
\hline IT artifact & Description & Reference \\
\hline $\begin{array}{l}\text { Distributed } \\
\text { ledger }\end{array}$ & $\begin{array}{l}\text { Distributed ledgers are } \\
\text { databases maintained at } \\
\text { different nodes instead of } \\
\text { at a central location. They } \\
\text { are identical, and each } \\
\text { contains all the } \\
\text { transactions. }\end{array}$ & $\begin{array}{l}\text { Beck et al. (2016), Ølnes } \\
\text { et al. (2017) }\end{array}$ \\
\hline $\begin{array}{l}\text { Consensus } \\
\text { mecha- } \\
\text { nism }\end{array}$ & $\begin{array}{l}\text { The consensus mechanism is } \\
\text { an algorithm that allows } \\
\text { the secure updating of } \\
\text { records. The ledgers can } \\
\text { only be updated when the } \\
\text { majority of nodes agree on } \\
\text { the value of the data. }\end{array}$ & $\begin{array}{l}\text { Notheisen et al. (2017), } \\
\text { Tapscott and Tapscott } \\
\text { (2016), L. Chen et al. } \\
\text { (2018) }\end{array}$ \\
\hline $\begin{array}{l}\text { Encryption } \\
\quad \text { mecha- } \\
\text { nism }\end{array}$ & $\begin{array}{l}\text { The encryption mechanism } \\
\text { consists of a public key } \\
\text { and a private key. The } \\
\text { public key is used to } \\
\text { encrypt the data, and the } \\
\text { private key is used to } \\
\text { authenticate the } \\
\text { participant. }\end{array}$ & $\begin{array}{l}\text { Ølnes et al. (2017), } \\
\text { Underwood (2016) }\end{array}$ \\
\hline $\begin{array}{l}\text { Smart } \\
\text { contracts }\end{array}$ & $\begin{array}{l}\text { Smart contracts are digitally } \\
\text { signed, computable, } \\
\text { self-executing agreements } \\
\text { among participants, trig- } \\
\text { gered by external events. } \\
\text { They automatically verify } \\
\text { and enforce the terms of } \\
\text { the agreement. }\end{array}$ & $\begin{array}{l}\text { Kshetri (2018), Gao et al. } \\
\text { (2017) }\end{array}$ \\
\hline $\begin{array}{l}\text { Immutable } \\
\text { audit } \\
\text { trail }\end{array}$ & $\begin{array}{l}\text { Participants of the ledger can } \\
\text { access, inspect, and add to } \\
\text { it. These historical } \\
\text { transactions then create an } \\
\text { audit trail. Because the } \\
\text { ledgers cannot be modified } \\
\text { or deleted, the audit trail is } \\
\text { immutable. }\end{array}$ & $\begin{array}{l}\text { Kshetri (2018), Underwood } \\
\text { (2016) }\end{array}$ \\
\hline
\end{tabular}

Adapted from Du et al. (2019)

To provide a brief overview of the functionality of the blockchain, we rely on its first use case: transacting bitcoins. Bitcoin is a peer-to-peer electronic cash system in which transactions are executed without the orchestration of an intermediary (Nakamoto 2008). The blockchain serves as a linear register of all past transactions within the bitcoin system. Previous transactions are documented in chained blocks and new transactions are added in new blocks. The blockchain functions as a general ledger in an accounting system. However, information is not stored centrally but is kept redundantly and decentralized across all nodes within the blockchain (Franco 2014). The members of the network administer the decentralized bitcoin system by corresponding protocols and active bitcoin transactions. Every member is eligible to review the locations to which the bitcoins have been transferred while remaining anonymous as an individual entity.

\section{Application of the Blockchain}

The blockchain has the potential to transform multiple industries and to significantly alter the fields of its application. Current research is predominately investigating four domains. First, the blockchain is strongly affecting financial services (Underwood 2016), especially the realms of accounting, auditing, and bank transfer (Wang and Kogan 2018). By eliminating a trusted third party, firms can significantly reduce transaction costs (Nowiński and Kozma 2017). Moreover, blockchain enables cross-border transactions in a short amount of time without having to account for currency exchange fees. Those characteristics disrupt traditional business models in the financial industry (Beinke et al. 2018).

Second, blockchain research has focused on the supply chain as the "most promising non-finance application of blockchain," which is believed "to deliver real Return on Investment at an early stage of blockchain development" (Reyna et al. 2018). The formal register of the blockchain enables every member of the system to identify and track the possession of a circulating item throughout the supply chain (Xu et al. 2018; Grewal et al. 2018). Incorporating such a transparent, verifiable, and shared database reduces current redundancy of every stakeholder operating and updating their database (Christidis and Devetsikiotis 2016). Another advantage of the blockchain is the ability to use connected objects installed in vehicles or storage refrigerators that track temperature to ensure that a product meets health standards along the supply chain (Pilkington 2016).

Third, blockchain can be related to the concept of twosided markets (Glaser 2017). Transaction parties usually need a trusted third party that facilitates the co-creation of value in the market (Hein et al. 2019b). These include platform intermediaries, such as Google, Uber, or Amazon, to provide a safe and reliable environment for transactions (Hein et al. 2016; Hein et al. 2018). However, blockchain eliminates the need for an intermediary by using a crowd of nodes on the system (Ying et al. 2018). Such technological change drives disintermediation (Xu et al. 2017) and decentralization of transactions between members of the system (Swan 2015). Simultaneously, it eliminates centralized risk, low efficiency, and high transaction costs (Ying et al. 2018). Blockchain technology can replace platform providers with a network of nodes (Subramanian 2018). For instance, the blockchain can potentially transform the reviewing and publishing market (Janze 2017) or even make musicians' careers more sustainable (O'Dair and Beaven 2017).

Fourth, we identify a wide range of research addressing the benefits of blockchain in the domain of social welfare (Li et al. 2018; Jiao et al. 2018). Blockchains solutions with their decentralized approach can leverage smart contracts and enable members of the system to contract service outcomes and automate contract conclusion (Cong and He 2019). A new 
member can signal her genuineness and participate in market transactions without incurring information asymmetry. For voting systems, blockchain technology can digitalize it, decrease voter tampering, and possibly improve voter participation (Kshetri and Voas 2018). Furthermore, blockchain solutions offer numerous opportunities in the healthcare industry (Mettler 2016), such as sharing patient data among clinics and research institutes (Smith and Dhillon 2017). Blockchain technology can address current concerns regarding security by leveraging cryptography, decentralization, and consensus mechanisms (L. Chen et al. 2017). With an universal exchangeable format, healthcare professionals and institutions can easily access sensitive data without putting it at risk (Swan 2015). Table 2 provides an overview of the identified fields of application and their respective benefits and assets.

In conclusion, we observe that current research investigating blockchain is mainly addressing technical aspects or elaborating possible applications and advantages for suitable industries. However, linking the blockchain technology to business models remains scarce.

\section{Blockchain technology and its implications for business models}

Blockchain technology offers multiple opportunities to innovate business models. Simultaneously, it imposes certain limitations on the design of new business models. On the advantageous side, blockchains provide various incentives to convert customers to blockchain-based business models (Nowiński and Kozma 2017; Subramanian 2018; Wörner et al. 2016). Depending on its implementation, these can include significant cost reductions emerging from disintermediation (Ying et al. 2018; Xu et al. 2017), faster transaction times (Underwood 2016), reduced record-keeping for customers

Table 2 Fields of Application of the Blockchain Technology

\begin{tabular}{|c|c|c|c|}
\hline $\begin{array}{l}\text { Field of } \\
\text { Application }\end{array}$ & Incentive & $\begin{array}{l}\text { Underlying } \\
\text { Asset }\end{array}$ & Example \\
\hline $\begin{array}{l}\text { Financial } \\
\text { services }\end{array}$ & $\begin{array}{l}\text { Cost optimization, } \\
\text { fraud reduction, } \\
\text { secure transactions }\end{array}$ & $\begin{array}{l}\text { Monetary } \\
\text { asset }\end{array}$ & $\begin{array}{r}\text { Direct transaction } \\
\text { between parties }\end{array}$ \\
\hline $\begin{array}{l}\text { Supply } \\
\text { chain }\end{array}$ & $\begin{array}{l}\text { Data traceability, } \\
\text { data verification, } \\
\text { reduction of } \\
\text { redundancy }\end{array}$ & Physical asset & $\begin{array}{l}\text { Shared database for } \\
\text { all members of } \\
\text { the whole value } \\
\text { chain }\end{array}$ \\
\hline $\begin{array}{r}\text { Two-sided } \\
\text { markets }\end{array}$ & $\begin{array}{l}\text { Disintermediation, } \\
\text { cost optimization, } \\
\text { risk } \\
\text { decentralization }\end{array}$ & $\begin{array}{l}\text { No asset } \\
\text { specifica- } \\
\text { tion }\end{array}$ & $\begin{array}{l}\text { Publishing market, } \\
\text { electricity supply }\end{array}$ \\
\hline $\begin{array}{l}\text { Social } \\
\quad \text { welfare }\end{array}$ & $\begin{array}{l}\text { Authentication, } \\
\text { security, reduction } \\
\text { of information } \\
\text { asymmetry }\end{array}$ & $\begin{array}{l}\text { User-specific } \\
\text { asset }\end{array}$ & $\begin{array}{l}\text { E-voting, electronic } \\
\text { health records, } \\
\text { smart contracts }\end{array}$ \\
\hline
\end{tabular}

resulting from the distributed ledger technology, and enhanced data traceability and verification.

The blockchain also offers an alternative approach for authenticating assets, thus setting it apart from centralized transaction systems that rely on an individual organization (Nowiński and Kozma 2017). Blockchains substitute for the trust between entities, which is usually provided by central transaction systems. More specifically, blockchain technology enables small, distributed stakeholders to exercise control over transactions and to hide their identity (Subramanian 2018). A layer of encryption shields all transactions. In combination with decentralization and complex validation mechanisms, blockchains ensure security while promoting trust among members of the system (Zhu and Zhou 2016; Underwood 2016).

Besides cost reduction, traceability, and security improvements, blockchains support the business model and organizational concept of a distributed autonomous organizations (DAO) (Adams et al. 2017; Chohan 2017; Shermin 2017; Elsden et al. 2018; Jun and Vasarhelyi 2017). DAOs exist without central governance, are monitored by shareholders, and are coordinated through smart contracts (Diallo et al. 2018; Chohan 2017). In this way, organizations can replace intermediaries enabling them to services at a lower price.

The implications on the business model and business practices are also related to the underlying assets of the blockchain (Jun and Vasarhelyi 2017). Assets circulating through the blockchain can be physical, virtual, monetary, or userspecific (Smith and Dhillon 2017; Y. Chen 2018; Jun and Vasarhelyi 2017). Implementing the blockchain technology for different assets provides various opportunities for changing and improving underlying business models and firm practices with customers, competitors, and suppliers.

Finally, engaging in a blockchain-based business model enables the use of cryptography and tokenization. Cryptography can substantially change a business model's value proposition as it ensures authenticity behind all interactions in the network (Christidis and Devetsikiotis 2016). Tokenization generally refers to substituting a confidential data component by a non-confidential data component (Liu 2016; Panarello et al. 2018). The business model can enhance its value by rewarding stakeholders with tokens or by accepting third-party tokens (Subramanian 2018). Tokens in the blockchain ledger can also be utilized as certificates to verify the ownership of assets among the firm and its stakeholders (Jun and Vasarhelyi 2017). Drawbacks of blockchain technology stem from diverse requirements, such as platform openness, integration of multiple features, such as identity and privacy (L. Chen et al. 2017), and interoperability as well as performance, scale, and stability (Underwood 2016).

In sum, blockchain solutions offer various opportunities to alter existing business models and create new ones. However, research lacks empirical studies on how blockchain technology impacts business models. 


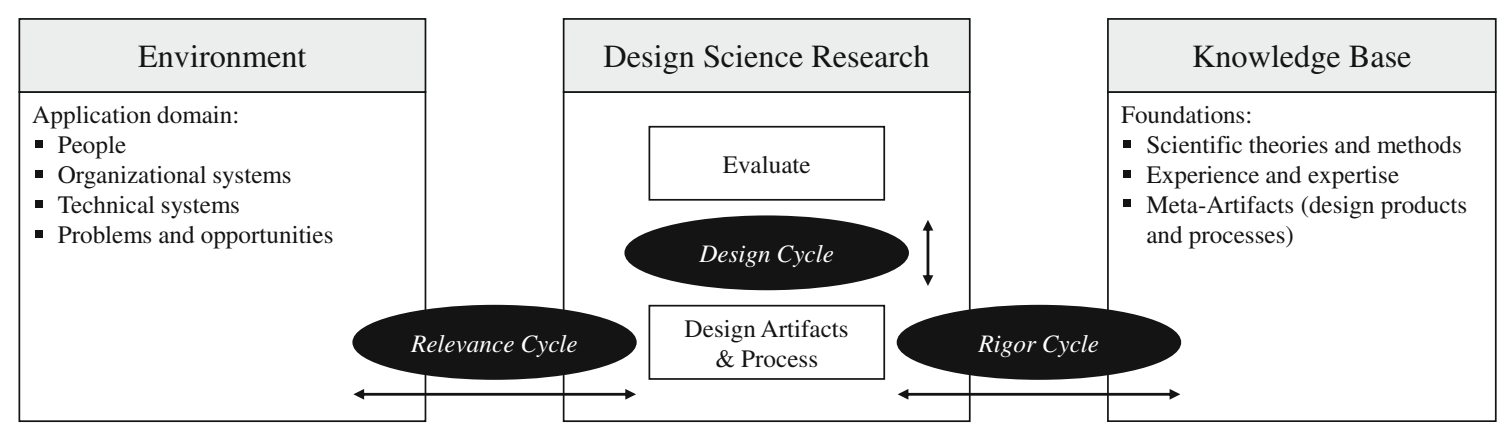

Fig. 1 Three Cycles of Design Science Research (Hevner 2007)

\section{Research method}

This paper employs design science research to develop a business model taxonomy and business model patterns for blockchain applications. By following this approach, we ensure practical relevance and scientific rigor (Hevner 2007). We iteratively build on the three cycles of design science research: the rigor cycle, relevance cycle, and design cycle (Hevner 2007). The rigor cycle incorporates the existing knowledge base and ensures that state-of-the-art research will be incorporated in the taxonomy. The relevance cycle connects design activities with real-world problems and strengthens the practical relevance of the taxonomy. The design cycle iteratively develops and evaluates the taxonomy. Figure 1 summarizes the three cycles and their relationships.

Conducting two iterations, we developed the blockchain business model taxonomy and blockchain business model patterns. Both iterations include rigor, relevance, and design cycles with a concluding evaluation. In the first iteration, we developed and evaluated the taxonomy by combining design science research with the taxonomy development method according to Nickerson et al. (2013). The second iteration builds and evaluates the archetypal business model patterns for blockchain technology. Figure 2 summarizes the iterations. In the following, we describe both iterations in more detail.

\section{Iteration 1: Develop taxonomy}

We started the first iteration with the rigor cycle and conducted a structured literature review, according to Webster and Watson (2002). We searched in the databases EBSCO, Scopus, and ScienceDirect following the search string "Blockchain*" AND ("Business Model" OR "Business Value" OR "Application" OR "Cryptography" OR "Smart Contracts"). To ensure that we include only high-quality, peer-reviewed journals, we used the VHB-JOURQAUL3 ranking. ${ }^{1}$ To further increase topicality and completeness of our review, we included conference papers of the AIS Library matching the keyword "Blockchain." Next, we screened the

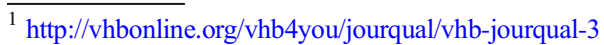

abstracts and eliminated irrelevant papers and duplicates, resulting in 45 remaining articles. The full-text screening excluded an additional 15 papers. The remaining 30 documents were the basis for the forward and backward search, which yielded 17 additional papers. In sum, the literature review generated 47 relevant articles. Table 6 in the appendix shows the concept matrix of the review. The related work section builds on these results.

In the first iteration of the design cycle for the interim result, we built on the results of the literature review. The design cycle is the heart of any design science research, considering the results of the rigor and relevance cycles iteratively as input for the construction and evaluation of the underlying artifact (Hevner 2007). As the artifact is aimed to be a taxonomy, we used the taxonomy development method according to Nickerson et al. (2013) to guide the design cycle. Hence, we first defined meta-characteristics (step 1 of Nickerson et al. (2013)). We chose the business model elements value proposition, value creation and delivery, and value capture as commonly used in other business model taxonomies (Täuscher and Laudien 2018; Remané et al. 2017) and in business model frameworks (Bocken et al. 2014; Wirtz et al. 2016). Second, we defined ending conditions for the iterative method (step 2 of Nickerson et al. (2013)), where we followed the conditions according to the authors. After setting the foundations of taxonomy development, we conducted the first design cycle.

From the literature review, we followed a conceptual-toempirical approach (Nickerson et al. 2013) to derive the dimensions and characteristics of the blockchain business model taxonomy. For business model dimensions, we refined the metacharacteristics from above with the dimensions service provision, key channel, key resources, key partner, target segment, revenue stream, and cost structure (Wirtz et al. 2016). For blockchain-specific aspects, we included four additional dimensions based on the literature review: Incentives (Nowiński and Kozma 2017; Subramanian 2018; Wörner et al. 2016), Underlying Asset (Smith and Dhillon 2017; Y. Chen 2018; Jun and Vasarhelyi 2017), DAO Affiliation (Chohan 2017; Adams et al. 2017; Shermin 2017; Elsden et al. 2018; Jun and Vasarhelyi 2017), and Token System (Panarello et al. 2018). This led to an initial, conceptual taxonomy. 


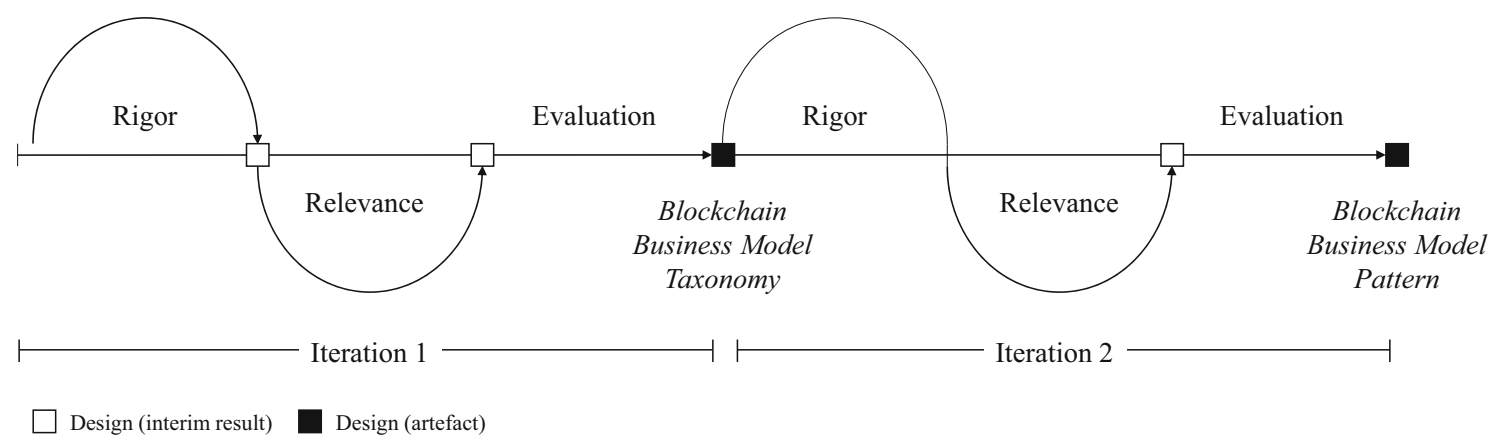

Fig. 2 Three Cycles of Design Science Research

For the relevance cycle, we compiled a database of firms that use blockchain technology as an integral part of their business model. We used CrunchBase as the world's largest database for new ventures (Marra et al. 2015). Because blockchain is a novel technology, the focus on new ventures enables us to analyze a breeding ground of emerging business models. We included all firms in the CrunchBase category "Blockchain" as of January 2018. We discovered 1237 firms as a possible sample. To ensure that our sample only contains successful and relevant firms, we used the following four criteria. First, we included only startups that already received funding to ensure data quality and potential success of firms (Krishna et al. 2016). Second, we excluded firms that went bankrupt or did not have an English homepage. Third, we analyzed the business model of the firms and included only firms that use blockchain technology as an integral part of their business models. For example, we excluded firms such as wallet providers or cryptocurrency exchange markets because they do not directly use the technology. Fourth, we analyzed the required information about the firms and excluded ones that did not provide sufficient information about their business model. After considering all factors, the final set of relevant blockchain firms covered 99 cases.

In the next design cycle, we continued the iterative taxonomy development with an empirical-to-conceptual approach (step 3 according to Nickerson et al. (2013)) building on the results of the previous rigor and relevance cycles. Using case survey guidelines (Larsson 1993) and taxonomy development steps (Nickerson et al. 2013), we classified all firms of our sample (step 4e) with the current taxonomy, identified new characteristics (step 5e), grouped these characteristics into dimensions, and revised the taxonomy (step 6e). In this coding process, we included the firms' webpages, existing technical or white papers, and information from CrunchBase to ensure data triangulation. This procedure led to the following new dimensions intermediation form, user diversification, customizability, value chain position, consensus mechanism, additional technology, and currency acceptance. We distinguished three dimensions, blockchain sourcing, blockchain type, and underlying blockchain as key resources and separated target segment into user and customer.
In the last step of the first iteration, we evaluated the taxonomy according to the ending conditions (step 7) of Nickerson et al. (2013). We were able to distinctly classify all firms of our sample without changing dimensions or characteristics. All objective and subjective ending conditions were fulfilled (Nickerson et al. 2013). To ensure statistical independence among dimensions, we analyzed their correlations. No dimension could be explained with another dimension or combinations of others. Hence, every dimension is important for explaining blockchain business models. Accordingly, we can show that taxonomy provides value, validity, and applicability (Hevner 2007).

\section{Iteration 2: Develop patterns}

In the second iteration, we derived the blockchain business model patterns. Again, we started with a rigor cycle incorporating the results of the literature review. The rigor cycle resulted in an initial set of patterns focused on application areas, such as financial services (Underwood 2016), supply chain (Reyna et al. 2018), two-sided markets (Glaser 2017), and social welfare (Li et al. 2018; Jiao et al. 2018).

In the subsequent relevance and design cycles, we performed a cluster analysis (Punj and Stewart 1983) on the sample of 99 firms and the underlying business model taxonomy to refine the initial business model patterns. We transformed the dataset of 99 firms and 22 dimensions of the taxonomy to dichotomous dummy variables for each characteristic of each dimension to measure distances. This process resulted in a vector with 84 binary entries for each firm. We performed hierarchical, agglomerative clustering using the Ward method (Kaufman and Rousseeuw 2009; Struyf et al. 1997). We used several approaches to determine the appropriate number of clusters, as the a priori definition of the number of clusters is a well-known issue in cluster analyses (Anderberg 2014). First, we used the point biserial correlation (Milligan and Cooper 1985) and the C-index (Hubert and Levin 1976), which both indicate five clusters as the best solution. Second, we qualitatively analyzed the five clusters to ensure that clusters are separable (inter-heterogeneity) and that single clusters share common characteristics (intra-homogeneity). 
Both are true for the chosen number of five clusters, indicating that the number of clusters is valid and useful.

For evaluation, we performed Fisher's exact test (Fisher and Bennett 1990) to confirm that the five patterns significantly differ in each dimension. We tested if the five clusters significantly vary in each of the 22 dimensions of the taxonomy. All five clusters differ in almost every dimension with a $p$ value lower than 5\%. Two dimensions show a $\mathrm{p}$ value lower than $10 \%$. Table 7 in the appendix shows the exact $p$ values. Moreover, we already qualitatively evaluated the patterns by confirming the number of clusters. The results indicate that the number of clusters and the clusters themselves are valid and applicable.

\section{Results}

\section{Business model taxonomy}

The resulting taxonomy contains 22 dimensions, each with two to five distinct characteristics. The taxonomy is visualized as a morphological box wherein a specific combination of characteristics describes the business model of a firm. The taxonomy contains dimensions in which the business models differ. Any further dimension would unnecessarily extend the taxonomy without providing additional information. Table 3 shows the complete taxonomy and Tables 8, 9, 10, and 11 in the appendix define each dimension and related characteristics.

\section{Business Model Patterns}

Five archetypal patterns emerged as salient and similar configurations of the business model taxonomy. The five patterns cover every business model of the sample firms, ranging from 10 firms in pattern 3 to 37 firms in pattern 2. Each pattern has different centers along the dimensions and characteristics in the blockchain business model taxonomy, demonstrating intra-homogeneity and inter-heterogeneity. Table 4 shows all five business model patterns and their definitions.

Table 5 provides an overview of the specific characteristics of each business model pattern. The table shows the differentiating characteristics of each pattern. These characteristics are based on a relative value of the frequency of a particular characteristic within one pattern to the overall frequency. In this manner, we can indicate characteristics that make a pattern unique and different from others. Consequently, not all firms of one pattern have precisely the same combination of characteristics. One pattern can cover more than one characteristic in some dimensions. In the following, we explain every pattern in detail by focusing on the most differentiating dimensions and characteristics for each pattern.

\section{Pattern 1: Blockchain for Business Integration}

The first pattern represents business models that provide the integration of blockchain solutions into existing value networks. Providers sell, for example, blockchain solutions for improving the data interoperability of firms in a supply chain from the Internet of things (IoT) devices. Providers increase data transparency for every participant in the blockchain ecosystem. Contractual time-stamped handshakes of IoT devices enable tracing and verifying data for all parties and, hence, prevent cyber-physical attacks. Customers and users are legal persons. The underlying asset of the blockchain is typically physical. The provider offers a system where IoT devices can generate data and communicate with the blockchain. Providers usually do not offer one standardized product but adjust it to the individual business needs of their customers. Participants store all relevant asset information in the blockchain. Hence, every member can continuously track the current state of the physical assets. Such distributed databases enable smart contracts and can provide additional business value for customers. The challenge is to integrate every member's system, typically ERP systems, in the blockchain solution to leverage its full potential.

Contrary to other patterns, providers offer individual blockchain solutions to customers with a specific business need instead of using the blockchain themselves. Hence, their value chain position is blockchain mediator. They typically use several underlying blockchain technologies and modified consensus mechanisms for a consortium of users. For revenue streams, operators typically do not provide a currency or token in the blockchain but charge their customers with periodic fees.

Modum $^{2}$ is a typical example of this pattern. They offer services for supply chain monitoring using IoT sensor devices to generate data (Modum 2018). They store data in a distributed database, granting access to every member on their blockchain. A characteristic of this pattern is that Modum provides its services for different industries, including pharmaceuticals and the supply chain in general.

\section{Pattern 2: Blockchain as Multi-Sided Platform}

The second pattern comprises providers that use blockchain solutions as a medium to operate a platform or multi-sided market. Customers and users are typically end users. Platform providers integrate firms to offer complementary products or services. Hence, they rely on industry partners as key partners. Some providers additionally enable users to offer or sell new assets using the blockchain and enable their customers to become complementors. The underlying asset is typically a virtual or a user-specific asset. The former primarily covers enhancing online-gaming experiences (e.g., DMarket ${ }^{3}$ ), whereas the latter

\footnotetext{
2 https://modum.io/

${ }^{3}$ https://dmarket.com/
} 
Table 3 Blockchain Business Model Taxonomy

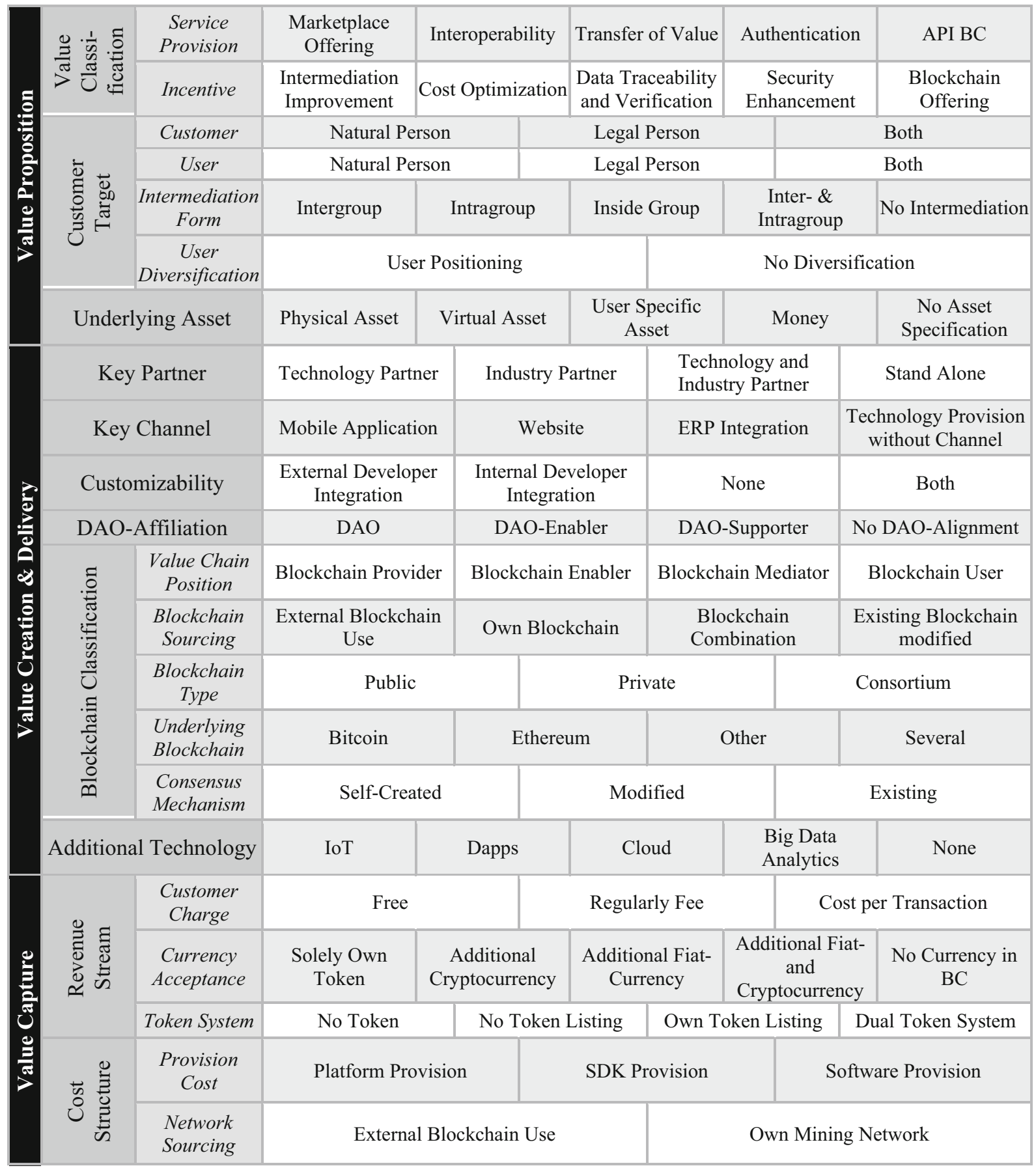

mainly targets the distribution and selling of data (e.g., BitClave $^{4}$ ) or labor (e.g., Bitjob ${ }^{5}$ ). Complementors offer their services through websites and do not offer customization. Providers typically use the blockchain framework Ethereum and existing consensus mechanisms because their business does not require specific blockchain modifications.

${ }^{4} \mathrm{https}: / / \mathrm{www} \cdot$ bitclave.com/

${ }^{5}$ https://bitjob.io/
Contrary to other patterns, the operators typically renounce relying on additional technology. Customers are mainly charged with transactional fees for propagating transactions into the blockchain. Some providers even offer two different tokens in their blockchain, for example for separating currency and assets (e.g., Decentraland ${ }^{6}$ ). 
Table 4 Blockchain Business Model Patterns

\begin{tabular}{lll}
\hline Pattern (P) & Definition & $\begin{array}{c}\text { Number of } \\
\text { firms }\end{array}$ \\
\hline $\begin{array}{ll}\text { P1: Blockchain for } \\
\text { Business Integration }\end{array}$ & $\begin{array}{l}\text { Provision of a standardized shared database } \\
\text { to improve interoperability among users } \\
\text { Provision of a marketplace without } \\
\text { regulating intermediaries }\end{array}$ & 44 \\
Platform & $\begin{array}{l}\text { Reinforcement of security aspects } \\
\text { by using several aspects of the blockchain } \\
\text { technology }\end{array}$ & 7 \\
P3: Blockchain for Security & $\begin{array}{l}\text { Provision of blockchain-APIs } \\
\text { Enablement of direct value transfer among peers }\end{array}$ & 21 \\
P4: Blockchain Technology as Offering & 13 \\
P5: Blockchain for Monetary Value & & \\
Transfer & &
\end{tabular}

An additional example is Storm, ${ }^{7}$ which provides a marketplace where different consumers can provide and fulfill microtasks. Storm earns rewards in the form of cryptocurrency. Similarly, Power Ledger ${ }^{8}$ offers its complementors the ability to sell self-generated electricity, thereby replacing traditional energy suppliers. A more disruptive example is Rega, ${ }^{9}$ which offers peer-to-peer insurance ("Crowdsurance"). It enables users to join forces in different insurance platforms, protect each other, and reduce costs by eliminating insurance firms as intermediaries.

\section{Pattern 3: Blockchain for Security}

The third pattern builds on cryptography and solutions that provide ownership clarification using cryptography. The solution can be applied to non-physical goods such as data or intellectual property. The asymmetric cryptography allows only the corresponding owner to alter either the data or its ownership. The distributed blockchain informs every participant regarding an ownership change.

Various firms address those features of blockchain technology to provide security of distributed data. The combination of trusted hardware and blockchain technology enable users to authenticate themselves securely. Providers offer these services to legal persons (customers) but target the needs of natural persons (users). The underlying assets are typically users' data. Providers often join forces with technology partners to offer security features. Those services often include additional technologies, such as cloud. Providers sell these without a specific channel. Most of our sample firms do not offer customizable solutions. However, they let firms use their solutions for various application areas. The value chain position is blockchain enabler. Many firms of these patterns use an existing, modified blockchain, typically Bitcoin for a private network with own consensus mechanism. Providers generate revenues with transaction fees and by generating their tokens.

\footnotetext{
$\overline{7 \text { https://www.stormx.io/ }}$

${ }^{8}$ https://www.powerledger.io/

${ }^{9}$ https://rega.life/
}

An example is Bluezelle, ${ }^{10}$ who provide decentralized storage. They build on the enhancement of privacy, reliability, and immutability of blockchain solutions in addition to reduced costs compared with single system databases. Similarly, NuCypher ${ }^{11}$ provides a privacy infrastructure for the decentralized web. Rivetz ${ }^{12}$ offers security features for existing assets that slowly become digital.

\section{Pattern 4: Blockchain Technology as Offering}

The fourth pattern offers blockchain-APIs to developers. Providers offer a blockchain infrastructure without any further specification of assets. Most customers are legal persons, whereas users also include natural persons. Compared with other patterns, they do not specify the underlying asset or provide a specific channel as they often distribute their API as an open-source. This isolated business model does not intermediate existing value chains and does not rely on strong partnerships. To separate from existing blockchains, providers develop their blockchain solution with modifications, such as modifying the underlying consensus mechanism. These modifications target more specific business needs. Therefore, we attribute those business models as DAO enabler with the value chain position blockchain enabler because they offer various implementations independent of the application area. Although they do not charge their customers, providers profit from the distribution of their tokens; they typically keep a portion of their tokens. A subsequent increase in demand leads to a higher value of those tokens and generates indirect income. Typically, they additionally accept other cryptocurrencies.

Examples include Qtum ${ }^{13}$ and Tezos. ${ }^{14}$ Both offer blockchain infrastructure to build decentralized apps, including the possibility of smart contracts and the implementation of the proof-of-

\footnotetext{
$\overline{{ }^{10} \mathrm{https}: / / \text { bluzelle.com/ }}$

${ }^{11} \mathrm{https}: / /$ nucypher.com/

$12 \mathrm{https}: / /$ rivetz.com/

13 https://qtum.org/

${ }^{14}$ https://tezos.com/
} 


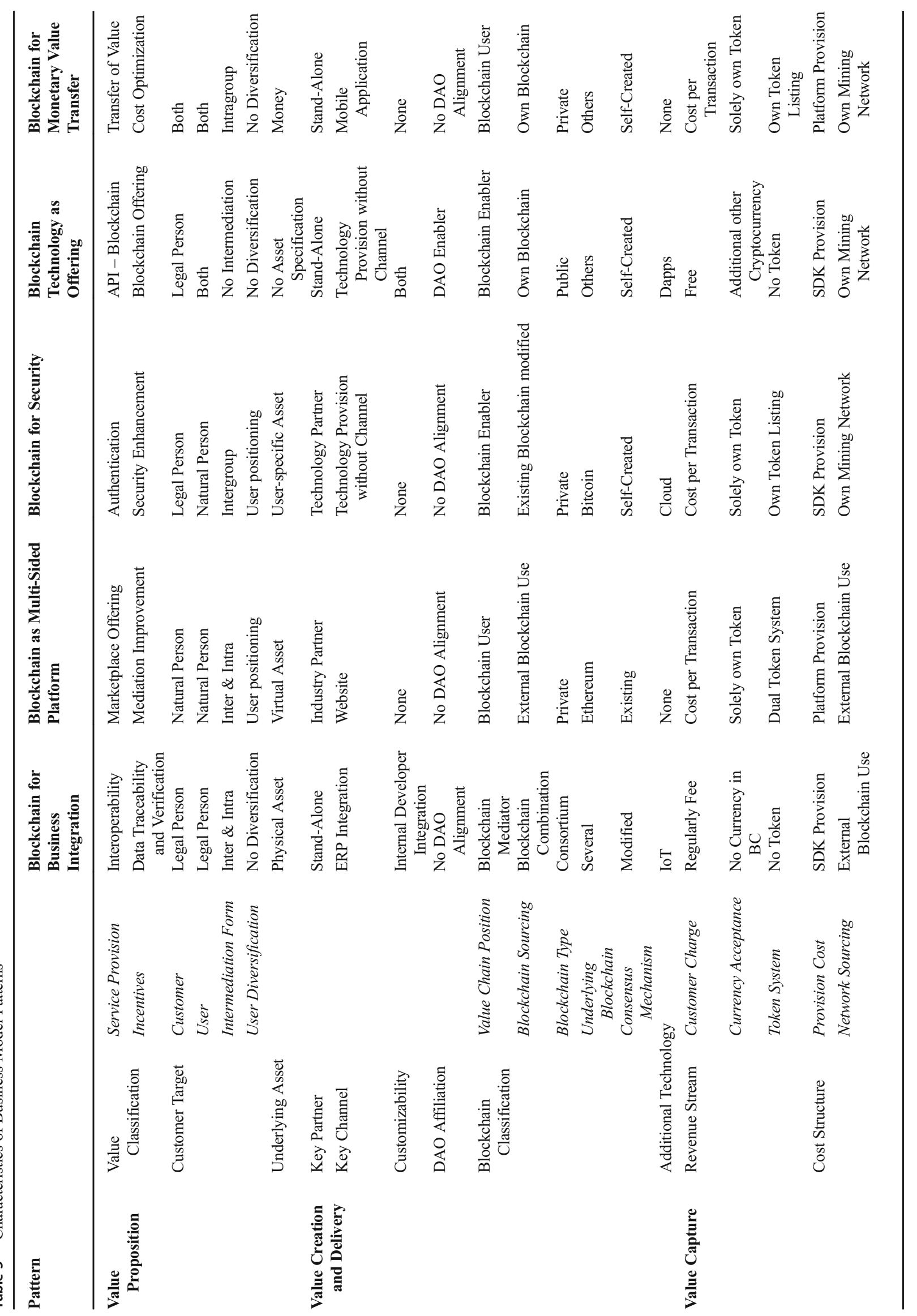


stake-algorithm. 0xproject ${ }^{15}$ created a blockchain for the decentralized exchange of assets. They focus on the tokenization and exchange aspect of blockchain technology.

\section{Pattern 5: Blockchain for Monetary Value Transfer}

The fifth pattern covers firms related to cryptocurrencies. Bitcoin, the first publicly introduced blockchain, developed an electronic cash system, which can replace intermediaries such as financial institutions and saves expenses. Currently, many firms discovered the various advantages of cryptocurrency and implemented their platforms for value transfer. These firms typically follow the Blockchain for Monetary Value Transfer business model pattern.

Providers target both legal and natural persons as their customers and users. The intermediation typically occurs within groups (intragroup), enabling the seamless transaction between different peers. Providers focus on money as the underlying asset. They do not heavily rely on partners and offer their services based on mobile applications without customizability as they aim for convenient and cheap transactions. Their value chain position is blockchain user. Providers typically use an external blockchain infrastructure and its underlying consensus mechanism. They do not introduce additional technology. Providers generate revenue by charging fees for every transaction propagated into the network. Furthermore, they distribute their tokens. To increase the value of their tokens, they allow for the transfer of only their tokens within their offerings.

An example is MakerDao, ${ }^{16}$ which aims to mitigate the lack of price-stability of cryptocurrencies. They minimize volatility by linking their tokens to an existing asset, such as fiat currency. ETHLend ${ }^{17}$ shifts their attention to the loan-aspect of currency. They reduce costs for creditor and debtor by removing crossborder transaction costs.

\section{Discussion}

The blockchain is a contemporary technology that has the potential to build the foundation for new business models (Iansiti and Lakhani 2017). However, there is a vast gap between the promised business value and actual value. In addition, it remains unclear how blockchain technology can influence the emergence of new business models.

To investigate the business value of blockchain, we follow a design science research approach (Hevner 2007) and develop a taxonomy of blockchain business models. The taxonomy is based on blockchain and business model literature, and 99 firms that use blockchain as a fundamental technology of their business

\footnotetext{
$\overline{15 \text { https://0x.org/ }}$

16 https://makerdao.com/

17 https:/ethlend.io/
}

model. Building on the taxonomy, we conducted a cluster analysis of the 99 firms to derive five archetypal business model patterns that illustrate how blockchain changes existing and triggers new business models.

The first pattern is Blockchain for Business Integration, which illustrates how companies provide a standardized shared database that improves interoperability among actors of a value chain. Second, Blockchain as Multi-Sided Platform, uses direct peer-topeer transactions to overcome restrictions on what can be offered by whom, hence, enabling new business models (Hein et al. 2019a). Those peer-to-peer transactions replace the need for centralized intermediaries (Hein et al. 2019c). Third, Blockchain for Security uses cryptography for security improvements and enables services that previously required physical authentication. Fourth, Blockchain Technology as Offering provide the technical infrastructure to enable blockchain-based business models. Fifth, Blockchain for Monetary Value Transfer uses cryptocurrencies and reduces transaction costs by eliminating the need for a trusted third party. The five patterns reveal that some, blockchain-based firms provide a new value proposition, while others constitute entirely new business models.

\section{Contribution to theory}

These findings contribute to the blockchain technology literature and the business model literature, including business model innovation.

\section{Contribution to business model literature}

The findings contribute in two ways to the business model literature. First, current literature acknowledges the potential of blockchain to change existing models and trigger entirely new business models in various industries (Iansiti and Lakhani 2017; Lacity 2018; Kshetri 2018; Wang and Kogan 2018) without empirically addressing how this change occurs. This study empirically investigates this phenomenon. The taxonomy enhances the understanding of how blockchain impacts business models. It can serve as a vocabulary that fosters a systematic description of blockchain business models. The taxonomy further illustrates opportunities for business model innovations without oversimplifying their complexity.

Moreover, the five archetypal business model patterns structure the impact of blockchain on business models and further support an understanding of it. The patterns demonstrate possible options for innovating a business model to utilize blockchain technology. We follow the call for analyzing business model patterns in a changing field (Remané et al. 2017). Further, we investigate the understudied topic of how new technologies, i.e., blockchain technology, influence traditional business models (Johnson et al. 2008; Bock and Wiener 2017). Hence, with a business model taxonomy and five archetypal 
business model patterns, we establish an understanding of how blockchain technology can impact existing and new business models.

Second, our research method illustrates how to derive a technology-specific business model taxonomy and business model patterns utilizing design science, taxonomy development, case survey, and cluster analysis. Design science serves as an overall research strategy with rigor, relevance, and design cycles (Hevner 2007). Guidelines of case surveys, taxonomy development, and cluster analysis further define these cycles. Case surveys provide the empirical base with a generalizable, crosssectional analysis (Larsson 1993). Taxonomy development then adds a systematic approach to integrate empirical and conceptual research (Nickerson et al. 2013). Cluster analysis finally ensures rigor in designing patterns (Kaufman and Rousseeuw 2009; Struyf et al. 1997). We build on all three levels of business models: real-world instances (cases), business model elements (taxonomy), and patterns (Osterwalder et al. 2005). Therefore, we leverage the full potential of the business model concept. Building on these methods, we show how to systematically derive a specific business model taxonomy and patterns that incorporate the existing knowledge base while ensuring practical relevance.

In sum, we first offer a shared language for describing, classifying, visualizing, and analyzing blockchain business models as a basis for future research. Second, our widely applicable research approach shows how to develop a business model taxonomy and how to identify business model patterns for a particular field of application. Hence, we contribute to the business model literature and the growing field of enterprise classifications based on business models (Täuscher and Laudien 2018).

\section{Contribution to Blockchain literature}

Literature about blockchain technology predominantly focuses on technological aspects (Nakamoto 2008; Wang and Kogan 2018; Eyal and Sirer 2018) and neglects its business value. Further, current research lacks empirical studies on how blockchain technology changes business models. This study extends blockchain literature by incorporating contemporary research on blockchain technology and its applications with recent developments from practice. By empirically and conceptually developing a blockchain business model taxonomy and extracting five archetypal patterns for blockchain business models, we enhance the understanding of how blockchain technology impacts business models and business value. The taxonomy indicates critical dimensions describing and analyzing businesses operating the blockchain technology. These dimensions include both technical aspects of blockchain solutions as well as elements of business models. The patterns further show tangible instances of how to leverage blockchain technology for business. By investigating blockchain business models, this paper opens up a business perspective on the technology-driven body of literature on blockchain technology.

\section{Implications for practice}

For practice, we provide a market overview enhancing the understanding of important aspects of blockchain business models by aggregating from many single entities to archetypal business model patterns. The taxonomy further can serve as a tool for business model innovation (Remané et al. 2016; Weking et al. 2018b). Practitioners can use the taxonomy and patterns to assess opportunities and barriers to integrating blockchain technology in their current business model. The characteristics of the taxonomy and the case examples may inspire practitioners to innovate their business model and allow managers to discover business model innovation opportunities. The five patterns guide the transformation process by specifying the relevant dimensions for a business model innovation. Firms can use patterns and related cases in an ideation phase to identify options for business model innovation toward blockchain and assess their implementation in the firm's context. The taxonomy and its business model patterns can be used as decision support for the evaluation and implementation of business ideas, such as building on an own blockchain solution or external blockchain solution, knowing ways to tokenize assets, or knowing ways to generate revenues.

Moreover, managers can build on the patterns to analyze their current market and identify opportunities and possible market entries for blockchain firms. The results can indicate white spots in the value network as entry points for blockchain provides and support decision making on whether and how to implement blockchain technology. Hence, the business model taxonomy, patterns, and related cases serve as technology-specific support for business model innovation.

\section{Limitations and future research}

This paper is subject to three main limitations. First, Nickerson et al. (2013) stated that taxonomies are never perfect and exhaustive. However, the taxonomy and patterns serve as the current state of blockchain business models. As the blockchain application field is evolving rapidly, further research can extend both results with future business models. 
Second, we build on the CrunchBase database, the world's largest startup database (Marra et al. 2015). Consequently, we focus on rather new ventures and cannot ensure that all firms that use blockchain technology are part of our sample. For example, we did not find the blockchain platform hyperledger in our cases, since its target group is rather large and incumbent firms. Hyperledger typically comes with licensing costs, whereas startups look for open blockchain solutions. However, the focus on new ventures allows us to better capture the new and still emerging field of blockchain applications. Furthermore, CrunchBase ensures proper data quality, and several other studies have already used it (Block and Sandner 2009; Marra et al. 2015; Werth and Boeert 2013; $\mathrm{Yu}$ and Perotti 2015). For data triangulation in the coding process, we consider the firms' webpages, existing technical or white papers, and CrunchBase information. This approach strengthens the validity of our dataset.

Third, we could not evaluate the archetypal business model patterns regarding business performance (cf. Weking et al. 2019). However, while blockchain applications are at an early stage to assess their success, the archetypal patterns indicate a fruitful avenue for blockchain business models and applications.

As blockchain technology is still emerging, and there is a gap between promised and actual business value, this research allows for future research of several aspects. The business potential of blockchain technology is still in its infancy and will evolve further. Future research can build on our taxonomy and archetypal business model patterns as constructs for further empirical studies, qualitative or quantitative. The taxonomy and its patterns serve as an extendable basis for further research providing the main dimensions and corresponding business model patterns. With this business model taxonomy, we want to encourage researchers to study and hypothesize about the relationships among concepts, as proposed by Glass and Vessey (1995). With increased progress of leveraged business value of blockchain technology in practice, research can extend the taxonomy and patterns toward a maturity model for blockchain business models. Moreover, researchers can build on the method integrating case surveys (Larsson 1993), taxonomy development (Nickerson et al. 2013), cluster analysis (Kaufman and Rousseeuw 2009; Struyf et al. 1997), and design science research (Hevner 2007) to develop business model taxonomies and patterns for various fields of application.

\section{Conclusion}

Current research emphasizes the technological advantages and the possible application fields of the blockchain technology (Kshetri 2018; Wang and Kogan 2018). Studies have stressed the ability of blockchain solutions to alter and disrupt existing business models and create entirely new business models (Iansiti and Lakhani 2017). However, current research about blockchain solutions focuses on only technological aspects (Nakamoto 2008; Wang and Kogan 2018; Eyal and Sirer 2018) and its application in practice (Kshetri 2018; Jun and Vasarhelyi 2017; Radanović and Likić 2018). Research does not explain a possible influence of blockchain technology on business models and lacks empirical investigations. Consequently, in practice, there is still a gap between possible business value and actual business value delivered.

Therefore, we develop a taxonomy of blockchain business models based on the literature and 99 firms building on blockchain technology. In addition, we identify five archetypal patterns of business models levering blockchain technology, namely Blockchain for Business Integration, Blockchain as Multi-Sided Platform, Blockchain for Security, Blockchain Technology as Offering, and Blockchain for Monetary Value Transfer. We build on design science research (Gregor and Hevner 2013) as a research strategy to guide the research methods case survey (Larsson 1993), taxonomy development (Nickerson et al. 2013), and cluster analysis (Kaufman and Rousseeuw 2009; Struyf et al. 1997).

This paper contributes to business model research by fostering an understanding of how technology, i.e., blockchain technology, influences existing and new business models. The blockchain business model taxonomy is a framework for describing, classifying, visualizing, and analyzing technologyspecific business models, whereas the archetypal patterns show typical instances of it. We also provide a research method to develop field-specific business model taxonomies and patterns by combining the three cycles of design science with case surveys, taxonomy development, and cluster analysis. The results contribute to blockchain literature by introducing the business model concept and combining business and technical aspects for blockchain business models. Findings show how blockchain technology can create business value and enrich the technology-driven blockchain literature. For practice, the taxonomy and patterns identify opportunities for leveraging blockchain technology and help understand important aspects of blockchain business models. Future research can build on our extendable taxonomy and archetypal patterns as constructs for further studies to shed more light on the still rapidly evolving topic of blockchain technology and its business models.

Acknowledgements The authors would like to thank all anonymous reviewers and the editors for their helpful comments and suggestions. This research is funded by the German Research Foundation (Deutsche Forschungsgemeinschaft - DFG) as part of the "Collaborative Research Center 768: Managing cycles in innovation processes - Integrated development of product service systems based on technical products' (TP C1), and the Center for Very Large Business Applications (CVLBA)@TUM. 


\section{Appendix}

\section{Literature Review}

Table 6 Concept Matrix of the Literature Review

\begin{tabular}{|c|c|c|c|c|c|c|c|c|c|}
\hline Reference & Cryptography & $\begin{array}{l}\text { Consensus } \\
\text { Mechanism }\end{array}$ & Token & $\begin{array}{l}\text { Smart } \\
\text { Contracts }\end{array}$ & DAO & Finance & $\begin{array}{l}\text { Citizen } \\
\text { Welfare }\end{array}$ & Marketplace & $\begin{array}{l}\text { Supply } \\
\text { Chain }\end{array}$ \\
\hline Wang and Kogan (2018) & $\mathrm{X}$ & & & & & $\mathrm{X}$ & & & \\
\hline Y. Chen (2018) & & & $\mathrm{X}$ & $\mathrm{X}$ & $\mathrm{X}$ & & & & \\
\hline Jun and Vasarhelyi (2017) & $\mathrm{X}$ & $\mathrm{X}$ & & & & $\mathrm{X}$ & & & \\
\hline Lacity (2018) & & & & & & & & $\mathrm{X}$ & $\mathrm{X}$ \\
\hline Radanović and Likić (2018) & & & & & & & $\mathrm{X}$ & & \\
\hline Gomber et al. (2018) & & & & & & $\mathrm{X}$ & & & \\
\hline Kshetri and Voas (2018) & & & & & & & $\mathrm{X}$ & $\mathrm{X}$ & \\
\hline Gökalp et al. (2018) & & & & & & & $\mathrm{X}$ & & \\
\hline Norta (2015) & & & & $\mathrm{X}$ & $\mathrm{X}$ & & & & \\
\hline Lin et al. (2018) & & $\mathrm{X}$ & & & & & & & \\
\hline Adams et al. (2017) & & & & & & $\mathrm{X}$ & $\mathrm{X}$ & & \\
\hline Shermin (2017) & & & $\mathrm{X}$ & $\mathrm{X}$ & $\mathrm{X}$ & & $\mathrm{X}$ & & \\
\hline Subramanian (2018) & & & & & & & & $\mathrm{X}$ & \\
\hline Kshetri (2018) & & & & & & & & & $\mathrm{X}$ \\
\hline Ying et al. (2018) & & & & & & & & $\mathrm{X}$ & \\
\hline Carlozo (2017) & $\mathrm{X}$ & $\mathrm{X}$ & & & & & & & \\
\hline Grewal et al. (2018) & & & & & & & & & $\mathrm{X}$ \\
\hline Woodside et al. (2017) & $\mathrm{X}$ & $\mathrm{X}$ & & & & & & & \\
\hline $\begin{array}{l}\text { Brammertz and Mendelowitz } \\
\text { (2018) }\end{array}$ & & & & & & $\mathrm{X}$ & & & \\
\hline Kim and Laskowski (2018) & & & & & & & & & $\mathrm{X}$ \\
\hline Kokina et al. (2017) & $\mathrm{X}$ & $\mathrm{X}$ & & & & $\mathrm{X}$ & & & $\mathrm{X}$ \\
\hline Kshetri (2017) & $\mathrm{X}$ & & & & & & $\mathrm{X}$ & & $\mathrm{X}$ \\
\hline Kavassalis et al. (2018) & & & & & & $\mathrm{X}$ & & & \\
\hline Beinke et al. (2018) & & & & & & $\mathrm{X}$ & & & \\
\hline Smith and Dhillon (2017) & & & & & & & $\mathrm{X}$ & & \\
\hline Oliveira et al. (2018) & & & $\mathrm{X}$ & & & & & & \\
\hline Hans et al. (2017) & & & & $\mathrm{X}$ & & & & & \\
\hline Elsden et al. (2018) & & & $\mathrm{X}$ & & & $\mathrm{X}$ & $\mathrm{X}$ & & \\
\hline Mashatan and Roberts (2017) & & & & & & $\mathrm{X}$ & & & \\
\hline Janze (2017) & & & & & & & & $\mathrm{X}$ & \\
\hline Nowiński and Kozma (2017) & & & & & & $\mathrm{X}$ & & & $\mathrm{X}$ \\
\hline Christidis and Devetsikiotis (2016) & $\mathrm{X}$ & $\mathrm{X}$ & $\mathrm{X}$ & $\mathrm{X}$ & & & & & \\
\hline Nakamoto (2008) & $\mathrm{X}$ & $\mathrm{X}$ & $\mathrm{X}$ & & & & & & \\
\hline Dai et al. (2018) & $\mathrm{X}$ & $\mathrm{X}$ & $\mathrm{X}$ & & & & & & \\
\hline Szabo (1997) & & & & $\mathrm{X}$ & & & & & \\
\hline O’Dair and Beaven (2017) & & & & & & & & $\mathrm{X}$ & \\
\hline Swan (2015) & $\mathrm{X}$ & $\mathrm{X}$ & & $\mathrm{X}$ & & $\mathrm{X}$ & $\mathrm{X}$ & $\mathrm{X}$ & \\
\hline Diedrich (2016) & & & $X$ & $\mathrm{X}$ & $X$ & & & & \\
\hline Reyna et al. (2018) & & & & & & $\mathrm{X}$ & $\mathrm{X}$ & $\mathrm{X}$ & $\mathrm{X}$ \\
\hline Mendling et al. (2018) & $\mathrm{X}$ & & & $\mathrm{X}$ & & & & & \\
\hline García-Bañuelos et al. (2017) & $\mathrm{X}$ & & & & & & & & \\
\hline Mashatan and Roberts (2017) & $\mathrm{X}$ & $\mathrm{X}$ & & & & & & & \\
\hline Zhao et al. (2016) & $\mathrm{X}$ & $\mathrm{X}$ & & & & & & & $\mathrm{X}$ \\
\hline $\begin{array}{l}\text { Fernández-Caramés and } \\
\text { Fraga-Lamas (2018) }\end{array}$ & $\mathrm{X}$ & $\mathrm{X}$ & & $\mathrm{X}$ & & $\mathrm{X}$ & $\mathrm{X}$ & $\mathrm{X}$ & $\mathrm{X}$ \\
\hline Panarello et al. (2018) & $\mathrm{X}$ & $\mathrm{X}$ & $\mathrm{X}$ & $\mathrm{X}$ & & & & & \\
\hline Treiblmaier (2018) & $\mathrm{X}$ & $\mathrm{X}$ & & $\mathrm{X}$ & & & & & $\mathrm{X}$ \\
\hline Eljazzar et al. (2018) & $\mathrm{X}$ & $\mathrm{X}$ & & & & & & & $\mathrm{X}$ \\
\hline
\end{tabular}




\section{Cluster Analysis}

Table 7 Fisher's Exact Test of Clusters

\begin{tabular}{|c|c|}
\hline Dimension & $\mathrm{p}$ value \\
\hline 1 & $2,20 \mathrm{E}-16 * * *$ \\
\hline 2 & $2,20 \mathrm{E}-16 * * *$ \\
\hline 3 & $2,20 \mathrm{E}-16 * * *$ \\
\hline 4 & $6,62 \mathrm{E}-07 * * *$ \\
\hline 5 & $2,20 \mathrm{E}-16 * * *$ \\
\hline 6 & $6,67 \mathrm{E}-04 * * *$ \\
\hline 7 & $2,20 \mathrm{E}-16 * * *$ \\
\hline 8 & $1,88 \mathrm{E}-10 * * *$ \\
\hline 9 & $7,30 \mathrm{E}-16 * * *$ \\
\hline 10 & $3,86 \mathrm{E}-08 * * *$ \\
\hline 11 & $1,95 \mathrm{E}-06 * * *$ \\
\hline 12 & $2,20 \mathrm{E}-16 * * *$ \\
\hline 13 & $5,07 \mathrm{E}-04 * * *$ \\
\hline 14 & 5,79 E-12 *** \\
\hline 15 & $5,05 \mathrm{E}-04 * * *$ \\
\hline 16 & $8,52 \mathrm{E}-02^{+}$ \\
\hline 17 & 9,73 E- $02^{+}$ \\
\hline 18 & 2,23 E-06 *** \\
\hline 19 & $4,33 \mathrm{E}-04 * * *$ \\
\hline 20 & $1,40 \mathrm{E}-02 *$ \\
\hline 21 & $2,20 \mathrm{E}-16 * * *$ \\
\hline 22 & 1,46 E-03 $* *$ \\
\hline
\end{tabular}

\section{Blockchain Business Model Taxonomy}

Table 8 Definitions of Blockchain Business Model Taxonomy Dimensions

\begin{tabular}{|c|c|c|c|}
\hline \multirow[t]{6}{*}{ Value Proposition } & $\begin{array}{l}\text { Value } \\
\text { Classi-fic- } \\
\text { ation }\end{array}$ & $\begin{array}{l}\text { Service } \\
\quad \text { Provision } \\
\text { Incentive }\end{array}$ & $\begin{array}{l}\text { Which service does the } \\
\text { operator provide? } \\
\text { How does the operator } \\
\text { incentives customers to use } \\
\text { its offering? }\end{array}$ \\
\hline & \multirow[t]{4}{*}{$\begin{array}{r}\text { Customer } \\
\text { Target }\end{array}$} & Customer & $\begin{array}{l}\text { To whom does the operator sell } \\
\text { its value proposition? }\end{array}$ \\
\hline & & User & $\begin{array}{l}\text { Who uses the operator's } \\
\text { business model? }\end{array}$ \\
\hline & & $\begin{array}{l}\text { Intermediation } \\
\quad \text { Form }\end{array}$ & $\begin{array}{l}\text { What kind of mediation does } \\
\text { the business model } \\
\text { incorporate? }\end{array}$ \\
\hline & & $\begin{array}{l}\text { User } \\
\quad \text { Diversifica- } \\
\quad \text { tion }\end{array}$ & $\begin{array}{l}\text { Does the operator diversify its } \\
\text { customer? }\end{array}$ \\
\hline & \multicolumn{2}{|c|}{ Underlying Asset } & $\begin{array}{l}\text { What kind of underlying asset } \\
\text { runs through the } \\
\text { blockchain? }\end{array}$ \\
\hline \multirow{10}{*}{$\begin{array}{l}\text { Value Creation \& } \\
\text { Delivery }\end{array}$} & \multirow{3}{*}{\multicolumn{2}{|c|}{$\begin{array}{l}\text { Key Partner } \\
\text { Key Channel } \\
\text { Customizability }\end{array}$}} & Key partnership of operator \\
\hline & & & Key channel of operator \\
\hline & & & $\begin{array}{l}\text { Does the operator allow for } \\
\text { customizability of its } \\
\text { offering? }\end{array}$ \\
\hline & \multicolumn{2}{|l|}{ DAO-Affiliation } & $\begin{array}{l}\text { How is the business model } \\
\text { affiliated to DAOs? }\end{array}$ \\
\hline & \multirow[t]{5}{*}{$\begin{array}{l}\text { Blockchain } \\
\text { Classificat- } \\
\text { ion }\end{array}$} & $\begin{array}{c}\text { Value Chain } \\
\text { Position }\end{array}$ & $\begin{array}{l}\text { What position does the } \\
\text { operator take within the } \\
\text { blockchain value chain? }\end{array}$ \\
\hline & & $\begin{array}{l}\text { Blockchain } \\
\text { Sourcing }\end{array}$ & $\begin{array}{l}\text { Sourcing of underlying } \\
\text { blockchain }\end{array}$ \\
\hline & & $\begin{array}{l}\text { Blockchain } \\
\text { Type }\end{array}$ & Type of underlying blockchain \\
\hline & & $\begin{array}{l}\text { Underlying } \\
\text { Blockchain }\end{array}$ & Root of underlying blockchain \\
\hline & & $\begin{array}{l}\text { Consensus } \\
\text { Mechanism }\end{array}$ & $\begin{array}{l}\text { Type of underlying consensus } \\
\text { mechanism }\end{array}$ \\
\hline & \multicolumn{2}{|c|}{ Additional Technology } & $\begin{array}{l}\text { Non-blockchain related } \\
\text { technologies, where the } \\
\text { Business Model builds on. }\end{array}$ \\
\hline \multirow[t]{5}{*}{ Value Capture } & \multirow[t]{3}{*}{$\begin{array}{l}\text { Revenue } \\
\text { Stream }\end{array}$} & $\begin{array}{l}\text { Customer } \\
\text { Charge }\end{array}$ & Revenue generation \\
\hline & & $\begin{array}{l}\text { Currency } \\
\text { Acceptance }\end{array}$ & $\begin{array}{l}\text { Which currencies does the } \\
\text { operator allow within its } \\
\text { offering? }\end{array}$ \\
\hline & & Token System & $\begin{array}{l}\text { How does the operator } \\
\text { distribute its token? }\end{array}$ \\
\hline & \multirow[t]{2}{*}{ Cost Structure } & Provision Cost & $\begin{array}{l}\text { What provision costs do } \\
\text { occur? }\end{array}$ \\
\hline & & $\begin{array}{l}\text { Network } \\
\text { Sourcing }\end{array}$ & Root of blockchain network \\
\hline
\end{tabular}


Table 9 Definition of Characteristics: Value Proposition

\begin{tabular}{|c|c|c|c|c|}
\hline \multirow[t]{27}{*}{$\begin{array}{l}\text { Value } \\
\text { Proposition }\end{array}$} & \multirow[t]{9}{*}{$\begin{array}{l}\text { Value } \\
\text { Classification }\end{array}$} & \multirow[t]{4}{*}{ Service Provision } & $\begin{array}{l}\text { Marketplace Offering } \\
\text { Interoperability }\end{array}$ & $\begin{array}{l}\text { Offering of marketplace without intermediary. } \\
\text { Alignment of separated databases. }\end{array}$ \\
\hline & & & Transfer of Value & Offering of environment to complete transactions. \\
\hline & & & Authentication & $\begin{array}{l}\text { Enhancement of authentication through advanced personalized } \\
\text { data security. }\end{array}$ \\
\hline & & & API - Blockchain & Offering of blockchain as open-source code. \\
\hline & & \multirow[t]{5}{*}{ Incentive } & $\begin{array}{l}\text { Intermediation } \\
\text { Improvement }\end{array}$ & Business model improves intermediation for customer. \\
\hline & & & Cost Optimization & Business model offers cost optimization for customer. \\
\hline & & & Security Enhancement & Business model increases customers' data security. \\
\hline & & & $\begin{array}{l}\text { Data Traceability and } \\
\text { Verification }\end{array}$ & $\begin{array}{l}\text { Business model increases data transparency and traceability for } \\
\text { customers. }\end{array}$ \\
\hline & & & Blockchain Offering & Business model offers blockchain infrastructure. \\
\hline & \multirow[t]{13}{*}{ Customer Target } & \multirow[t]{3}{*}{ Customer } & Natural Person & Customers are individual human beings. \\
\hline & & & Legal Person & Customers are private or public organizations. \\
\hline & & & Both & Customers are human beings and organizations. \\
\hline & & \multirow[t]{3}{*}{ User } & Natural Person & Users are individual human beings. \\
\hline & & & Legal Person & Users are private or public organizations. \\
\hline & & & Both & Users are human beings and organizations. \\
\hline & & \multirow{5}{*}{$\begin{array}{l}\text { Intermediation } \\
\quad \text { Form }\end{array}$} & Intergroup & Business model intermediates vertically along value chain. \\
\hline & & & Intragroup & Business model intermediates horizontally along value chain. \\
\hline & & & Inside-Group & Business model intermediates within one group of value chain. \\
\hline & & & Inter \& Intra & $\begin{array}{l}\text { Business model intermediates horizontally and vertically along } \\
\text { value chain. }\end{array}$ \\
\hline & & & No Intermediation & Business model provides no intermediation. \\
\hline & & \multirow{7}{*}{$\begin{array}{l}\text { User } \\
\quad \text { Diversification }\end{array}$} & User positioning & Business model classifies existing user into groups. \\
\hline & & & No Diversification & Business model does not classify its users. \\
\hline & \multirow[t]{5}{*}{ Underlying Asset } & & Physical Asset & Underlying asset is physical. \\
\hline & & & Virtual Asset & Underlying asset is virtual. \\
\hline & & & User specific Asset & Underlying asset is user-personalized (IP, Labor, Data, ...). \\
\hline & & & Money & Underlying asset represents equivalent of money. \\
\hline & & & No Asset Specification & Underlying asset is not specified. \\
\hline
\end{tabular}


Table 10 Definition of Characteristics: Value Creation \& Delivery

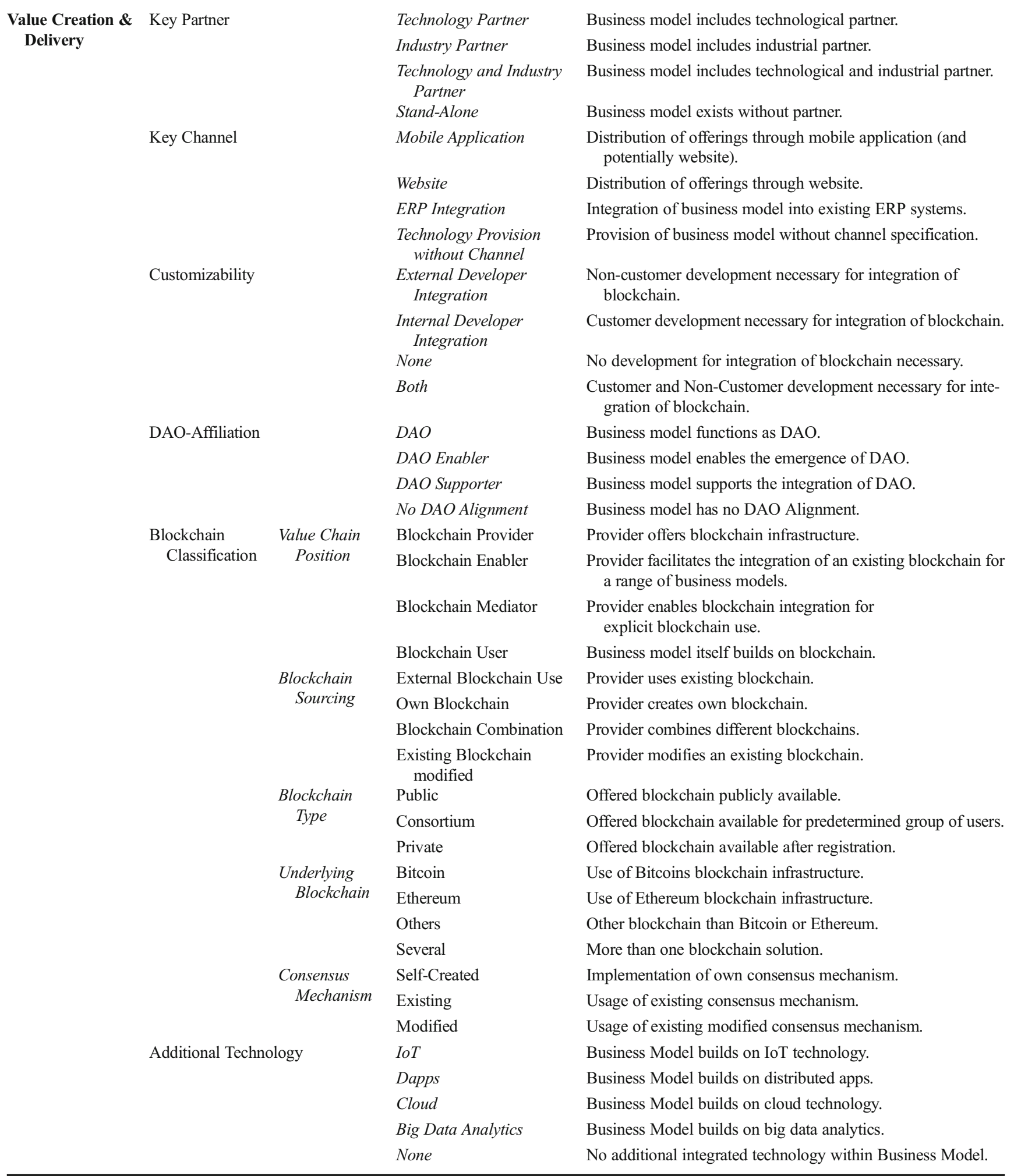


Table 11 Definition of Characteristics: Value Capture

\begin{tabular}{|c|c|c|c|c|}
\hline \multirow{17}{*}{$\begin{array}{l}\text { Value } \\
\text { Capture }\end{array}$} & \multirow{12}{*}{$\begin{array}{l}\text { Revenue } \\
\text { Stream }\end{array}$} & \multirow[t]{3}{*}{ Customer Charge } & Free & Free of charge for customers. \\
\hline & & & Regularly Fee & Customer charged by regularly fee. \\
\hline & & & Cost per Transaction & Customer charged with transaction costs. \\
\hline & & \multirow{5}{*}{$\begin{array}{l}\text { Currency } \\
\text { Acceptance }\end{array}$} & Solely own Token & Distribution of solely own tokens. \\
\hline & & & $\begin{array}{l}\text { Additional other } \\
\text { Cryptocurrency }\end{array}$ & Distribution of own tokens and acceptance of other cryptocurrencies. \\
\hline & & & Additional Fiat-Currency & Distribution of own tokens and acceptance of fiat currencies. \\
\hline & & & $\begin{array}{l}\text { Additional Fiat- and } \\
\text { Cryptocurrency }\end{array}$ & $\begin{array}{l}\text { Distribution of own tokens and acceptance of fiat currencies and } \\
\text { cryptocurrencies. }\end{array}$ \\
\hline & & & No Currency in Blockchain & No trading within business model and thus no currency existing. \\
\hline & & \multirow[t]{4}{*}{ Token System } & No Token & No tokens exist. \\
\hline & & & Own Token Listing & Business model lists one type of own tokens. \\
\hline & & & Dual Token System & Business model lists several own tokens. \\
\hline & & & No Token Listing & Business model lists no own token although own token exists. \\
\hline & \multirow{5}{*}{$\begin{array}{l}\text { Cost } \\
\text { Structure }\end{array}$} & \multirow[t]{3}{*}{ Provision Cost } & Platform Provision & Providing a platform only without supporting software. \\
\hline & & & SDK Provision & Operator provides source code. \\
\hline & & & Software Provision & Operator provides blockchain with supporting software. \\
\hline & & \multirow{2}{*}{$\begin{array}{l}\text { Network } \\
\quad \text { Sourcing }\end{array}$} & External Blockchain Use & Business model uses external blockchain infrastructure. \\
\hline & & & Own Mining Network & Business model uses own blockchain infrastructure. \\
\hline
\end{tabular}

Open Access This article is licensed under a Creative Commons Attribution 4.0 International License, which permits use, sharing, adaptation, distribution and reproduction in any medium or format, as long as you give appropriate credit to the original author(s) and the source, provide a link to the Creative Commons licence, and indicate if changes were made. The images or other third party material in this article are included in the article's Creative Commons licence, unless indicated otherwise in a credit line to the material. If material is not included in the article's Creative Commons licence and your intended use is not permitted by statutory regulation or exceeds the permitted use, you will need to obtain permission directly from the copyright holder. To view a copy of this licence, visit http://creativecommons.org/licenses/by/4.0/.

\section{References}

Adams, R., Parry, G., Godsiff, P., \& Ward, P. (2017). The future of money and further applications of the blockchain. [Article]. Strategic Change, 26(5), 417-422.

Anderberg, M. R. (2014). Cluster analysis for applications: Probability and mathematical statistics: A series of monographs and textbooks (Vol. 19). New York: Academic.

Beck, R., Czepluch, J. S., Lollike, N., \& Malone, S. (2016). BlockchainThe gateway to trust-free cryptographic transactions. Paper presented at the twenty-fourth European Conference on Information Systems (ECIS), Istanbul, 2016.

Beinke, J. H., Nguyen, D., \& Teuteberg, F. (2018). Towards a business model taxonomy of startups in the finance sector using blockchain. Paper presented at the thirty ninth International Conference on Information Systems (ICIS), San Francisco, 2018.

Block, J., \& Sandner, P. (2009). Necessity and opportunity entrepreneurs and their duration in self-employment: Evidence from German micro data. Journal of Industry, Competition and Trade, 9(2), 117137.

Bock, M., \& Wiener, M. (2017). Towards a taxonomy of digital business models - Conceptual dimensions and empirical illustrations. Paper presented at the thirty eighth International Conference on Information Systems (ICIS 2017), Seoul, South Korea, 2017.

Bocken, N. M., Short, S. W., Rana, P., \& Evans, S. (2014). A literature and practice review to develop sustainable business model archetypes. Journal of Cleaner Production, 65, 42-56.

Brammertz, W., \& Mendelowitz, A. (2018). From digital currencies to digital finance: The case for a smart financial contract standard. The Journal of Risk Finance, 19(1), 76-92.

Carlozo, L. (2017). Understanding blockchain. Journal of Accountancy, 224(2), 1-1.

Chen, Y. (2018). Blockchain tokens and the potential democratization of entrepreneurship and innovation. Business Horizons, 61(4), 567575.

Chen, L., Xu, L., Shah, N., Diallo, N., Gao, Z., Lu, Y., et al. (2017). Unraveling blockchain based crypto-currency system supporting oblivious transactions: A formalized approach. Paper presented at the ACM workshop on Blockchain, Cryptocurrencies and Contracts, 2017.

Chen, L., Xu, L., Gao, Z., Lu, Y., \& Shi, W. (2018). Protecting early stage proof-of-work based public blockchain. Paper presented at the 48th annual IEEE/IFIP International Conference on Dependable Systems and Networks Workshops (DSN-W), 2018.

Chohan, U. W. (2017). The decentralized autonomous organization and governance issues (Notes on the 21st century). University of New South Wales, Canberra, School of Business and Economics.

Christidis, K., \& Devetsikiotis, M. (2016). Blockchains and smart contracts for the internet of things. IEEE Access, 4, 2292-2303.

Cong, L. W., \& He, Z. (2019). Blockchain disruption and smart contracts. The Review of Financial Studies, 32(5), 1754-1797.

Dai, F., Shi, Y., Meng, N., Wei, L., \& Ye, Z. (2018). From Bitcoin to cybersecurity: A comparative study of blockchain application and security issues. In 2017 4th International Conference on Systems and Informatics, ICSAI 2017, 2018 (Vol. 2018-January, pp. 975979).

Diallo, N., Shi, W., Xu, L., Gao, Z., Chen, L., Lu, Y., et al. (2018). eGovDAO: A better government using blockchain based decentralized autonomous organization. Paper presented at the eDemocracy \& eGovernment (ICEDEG), Ambato, 2018. 
Diedrich, H. (2016). Ethereum: Blockchains, digital assets, smart contracts, decentralized autonomous organizations. Sydney: Wildfire Publishing.

Du, W. D., Pan, S. L., Leidner, D. E., \& Ying, W. (2019). Affordances, experimentation and actualization of FinTech: A blockchain implementation study. The Journal of Strategic Information Systems, 28(1), 50-65.

Eljazzar, M., Amr, M., Kassem, S., \& Ezzat, M. (2018). Merging supply chain and blockchain technologies. arXiv preprint arXiv:.04149.

Elsden, C., Manohar, A., Briggs, J., Harding, M., Speed, C., \& Vines, J. (2018). Making sense of blockchain applications: A typology for HCI. Paper presented at the conference on Human Factors in Computing Systems, 2018.

Eyal, I., \& Sirer, E. G. (2018). Majority is not enough: Bitcoin mining is vulnerable. Communications of the ACM, 61(7), 95-102.

Fernández-Caramés, T. M., \& Fraga-Lamas, P. (2018). A review on the use of blockchain for the internet of things. IEEE Access (in press).

Fisher, R. A., \& Bennett, J. H. (1990). Statistical methods, experimental design, and scientific inference. Oxford: Oxford University Press.

Foss, N. J., \& Saebi, T. (2017). Fifteen years of research on business model innovation: How far have we come, and where should we go? Journal of Management, 43(1), 200-227.

Franco, P. (2014). Understanding bitcoin: Cryptography, engineering and economics. Chichester: Wiley.

Frankenberger, K., Weiblen, T., Csik, M., \& Gassmann, O. (2013). The 4I-framework of business model innovation: A structured view on process phases and challenges. International Journal of Product Development, 18(3-4), 249-273.

Frankenberger, K., Weiblen, T., \& Gassmann, O. (2014). The antecedents of open business models: An exploratory study of incumbent firms. R\&D Management, 44(2), 173-188.

Gao, Z., Xu, L., Chen, L., Shah, N., Lu, Y., \& Shi, W. (2017). Scalable blockchain based smart contract execution. Paper presented at the IEEE 23rd International Conference on Parallel and Distributed Systems (ICPADS), 2017.

García-Bañuelos, L., Ponomarev, A., Dumas, M., \& Weber, I. (2017). Optimized execution of business processes on blockchain. Paper presented at the International Conference on Business Process Management, 2017.

Gassmann, O., Frankenberger, K., \& Sauer, R. (2017). A primer on theoretically exploring the field of business model innovation. The European Business Review (TEBR), January-February.

Glaser, F. (2017). Pervasive decentralisation of digital infrastructures: A framework for blockchain enabled system and use case analysis. Paper presented at the proceedings of the 50th Hawaii International Conference on System Sciences, Hawaii, 2017.

Glass, R. L., \& Vessey, I. (1995). Contemporary application-domain taxonomies. IEEE Software, 4, 63-76.

Gökalp, E., Gökalp, M. O., Çoban, S., \& Eren, P. E. (2018). Analysing opportunities and challenges of integrated blockchain technologies in healthcare. Paper presented at the EuroSymposium on Systems Analysis and Design, 2018.

Gomber, P., Kauffman, R. J., Parker, C., \& Weber, B. W. (2018). On the Fintech revolution: Interpreting the forces of innovation, disruption, and transformation in financial services. Journal of Management Information Systems, 35(1), 220-265.

Gregor, S., \& Hevner, A. R. (2013). Positioning and presenting design science research for maximum impact. MIS Quarterly, 37(2), 337 335 .

Grewal, D., Motyka, S., \& Levy, M. (2018). The evolution and future of retailing and retailing education. Journal of Marketing Education, 40(1), 85-93.

Hans, R., Zuber, H., Rizk, A., \& Steinmetz, R. (2017). Blockchain and smart contracts: Disruptive technologies for the insurance market. Paper presented at the 23th Americas Conference on Information Systems (AMCIS), Boston.
Hein, A., Schreieck, M., Wiesche, M., \& Krcmar, H. (2016). Multiplecase analysis on governance mechanisms of multi-sided platforms. In Proceedings of the Multikonferenz. Wirtschaftsinformatik, Ilmenau, Germany, 2016 (Vol. 3, pp. 1613-1625).

Hein, A., Böhm, M., \& Krcmar, H. (2018). Tight and loose coupling in evolving platform ecosystems: The cases of Airbnb and Uber. In W. Abramowicz \& A. Paschke (Eds.), Business Information Systems. BIS 2018. Lecture notes in business information processing (Vol. 320, pp. 295-306). Berlin/Cham: Springer.

Hein, A., Schreieck, M., Wiesche, M., Böhm, M., \& Krcmar, H. (2019a). The emergence of native multi-sided platforms and their influence on incumbents. Electronic Markets, 29(4), 631-647.

Hein, A., Weking, J., Schreieck, M., Wiesche, M., Böhm, M., \& Krcmar, H. (2019b). Value co-creation practices in business-to-business platform ecosystems. Electronic Markets, 29(3), 503-518.

Hein, A., Schreieck, M., Riasanow, T., Soto Setzke, D., Wiesche, M., Böhm, M., \& Krcmar, H. (2019c). Digital platform ecosystems. Electronic Markets, 1-12 (in print).

Hermes, S., Böhm, M., \& Krcmar, H. (2019). Business model innovation and stakeholder: Exploring mechanisms and outcomes of value creation and destruction. Paper presented at the 14. Internationale Tagung Wirtschaftsinformatik (WI 2019) Siegen, Germany.

Hevner, A. R. (2007). A three cycle view of design science research. Scandinavian Journal of Information Systems, 19(2), 4.

Hubert, L. J., \& Levin, J. R. (1976). A general statistical framework for assessing categorical clustering in free recall. Psychological Bulletin, 83(6), 1072.

Iansiti, M., \& Lakhani, K. R. (2017). The truth about blockchain. Harvard Business Review, 95(1), 118-127.

Janze, C. (2017). Design of a decentralized peer-to-peer reviewing and publishing market. Paper presented at the 25th European Conference on Information Systems (ECIS), Guimarães, Portugal.

Jiao, Y., Wang, P., Niyato, D., \& Xiong, Z. (2018). Social welfare maximization auction in edge computing resource allocation for mobile blockchain. Paper presented at the IEEE International Conference on Communications (ICC), 2018.

Johnson, M. W., Christensen, C. M., \& Kagermann, H. (2008). Reinventing your business model. Harvard Business Review, 86(12), 57-68.

Jun, D., \& Vasarhelyi, M. A. (2017). Toward blockchain-based accounting and assurance. Journal of Information Systems, 31(3), 5-21.

Kaufman, L., \& Rousseeuw, P. J. (2009). Finding groups in data: An introduction to cluster analysis (Wiley Series in Probability and Statistics). Hoboken: Wiley.

Kavassalis, P., Stieber, H., Breymann, W., Saxton, K., \& Gross, F. J. (2018). An innovative RegTech approach to financial risk monitoring and supervisory reporting. The Journal of Risk Finance, 19(1), $39-55$.

Kim, H. M., \& Laskowski, M. (2018). Toward an ontology-driven blockchain design for supply-chain provenance. Intelligent Systems in Accounting, Finance and Management, 25(1), 18-27.

Kokina, J., Mancha, R., \& Pachamanova, D. (2017). Blockchain: Emergent industry adoption and implications for accounting. Journal of Emerging Technologies in Accounting, 14(2), 91-100.

Krishna, A., Agrawal, A., \& Choudhary, A. (2016). Predicting the outcome of startups: Less failure, more success. Paper presented at the 16th International Conference on Data Mining Workshops (ICDMW), 2016.

Kshetri, N. (2017). Blockchain's roles in strengthening cybersecurity and protecting privacy. Telecommunications Policy, 41(10), 1027-1038.

Kshetri, N. (2018). Blockchain's roles in meeting key supply chain management objectives. International Journal of Information Management, 39, 80-89.

Kshetri, N., \& Voas, J. (2018). Blockchain-enabled E-voting. IEEE Software, 35(4), 95-99. 
Lacity, M. C. (2018). Addressing key challenges to making enterprise blockchain applications a reality. MIS Quarterly Executive, 17(3).

Larsson, R. (1993). Case survey methodology: Quantitative analysis of patterns across case studies. Academy of Management Journal, 36(6), 1515-1546.

Li, J., Qu, F., Tu, X., Fu, T., Guo, J., \& Zhu, J. (2018). Public philanthropy logistics platform based on blockchain technology for social welfare maximization. Paper presented at the 2018 8th International Conference on Logistics, Informatics and Service Sciences (LISS).

Lin, C., He, D., Huang, X., Choo, K.-K. R., Vasilakos, A. V., \& Applications, C. (2018). BSeIn: A blockchain-based secure mutual authentication with fine-grained access control system for industry 4.0. Journal of Network, 116, 42-52.

Liu, P. T. S. (2016). Medical record system using blockchain, big data and tokenization. Paper presented at the International Conference on Information and Communications Security, 2016.

Marra, A., Antonelli, P., Dell'Anna, L., \& Pozzi, C. (2015). A network analysis using metadata to investigate innovation in clean-tech-implications for energy policy. Energy Policy, 86, 17-26.

Mashatan, A., \& Roberts, Z. (2017). An enhanced real estate transaction process based on blockchain technology. Paper presented at the twenty-third Americas Conference on Information Systems (AMCIS), Boston

Massa, L., Tucci, C. L., \& Afuah, A. (2017). A critical assessment of business model research. Academy of Management Annals, 11(1), 73-104.

Mendling, J., Weber, I., Aalst, W. V. D., Brocke, J. V., Cabanillas, C., Daniel, F., et al. (2018). Blockchains for business process management-challenges and opportunities. ACM Transactions on Management Information Systems, 9(1), 4.

Mettler, M. (2016). Blockchain technology in healthcare: The revolution starts here. Paper presented at the 18th international conference on e-Health Networking, Applications and Services (Healthcom), 2016.

Milligan, G. W., \& Cooper, M. C. (1985). An examination of procedures for determining the number of clusters in a data set. Psychometrika, 50(2), 159-179.

Modum. (2018). Homepage of modum. https://modum.io/. Accessed 12/ $01 / 2018$.

Nakamoto, S. (2008). Bitcoin: A peer-to-peer electronic cash system.

Nickerson, R. C., Varshney, U., \& Muntermann, J. (2013). A method for taxonomy development and its application in information systems. European Journal of Information Systems, 22(3), 336-359.

Norta, A. (2015). Creation of smart-contracting collaborations for decentralized autonomous organizations. Paper presented at the International Conference on Business Informatics Research.

Notheisen, B., Cholewa, J. B., \& Shanmugam, A. P. (2017). Trading realworld assets on blockchain. Business \& Information Systems Engineering, 59(6), 425-440.

Nowiński, W., \& Kozma, M. (2017). How can blockchain technology disrupt the existing business models? Entrepreneurial Business and Economics Review, 5(3), 173-188.

O'Dair, M., \& Beaven, Z. (2017). The networked record industry: How blockchain technology could transform the record industry. Strategic Change, 26(5), 471-480.

Oliveira, L., Zavolokina, L., Bauer, I., \& Schwabe, G. (2018). To token or not to token: Tools for understanding blockchain tokens. Paper presented at the Thirty Ninth International Conference on Information Systems, San Francisco.

Ølnes, S., Ubacht, J., \& Janssen, M. (2017). Blockchain in government: Benefits and implications of distributed ledger technology for information sharing. Government Information Quarterly, 34(3), 355364.

Osterwalder, A., Pigneur, Y., \& Tucci, C. L. (2005). Clarifying business models: Origins, present, and future of the concept.
Communications of the Association for Information Systems, 16(1), 1-25.

Panarello, A., Tapas, N., Merlino, G., Longo, F., \& Puliafito, A. (2018). Blockchain and IoT integration: A systematic survey. Sensors, 18(8), 2575.

Pilkington, M. (2016). 11 Blockchain technology: Principles and applications. Research handbook on digital transformations, 225.

Punj, G., \& Stewart, D. W. (1983). Cluster analysis in marketing research: Review and suggestions for application. Journal of Marketing Research, 20(2), 134-148.

Radanović, I., \& Likić, R. (2018). Opportunities for use of blockchain technology in medicine. Applied Health Economics and Health Policy, 16(5), 583-590.

Remané, G., Nickerson, R. C., Hanelt, A., Tesch, J. F., \& Kolbe, L. M. (2016). A taxonomy of carsharing business models. Paper presented at the thirty seventh International Conference on Information Systems (ICIS), Dublin, Ireland.

Remané, G., Hanelt, A., Tesch, J. F., \& Kolbe, L. M. (2017). The business model pattern database - A tool for systematic business model innovation. International Journal of Innovation Management, 21(1), 1750004.

Reyna, A., Martín, C., Chen, J., Soler, E., \& Díaz, M. (2018). On blockchain and its integration with IoT. Challenges and opportunities. Future Generation Computer Systems, 88, 173-190.

Shafer, S. M., Smith, H. J., \& Linder, J. C. (2005). The power of business models. Business Horizons, 48(3), 199-207.

Shermin, V. (2017). Disrupting governance with blockchains and smart contracts. Strategic Change, 26(5), 499-509.

Short, C. (2018). Blockchain applications. Modern Trader, 1(539), 21.

Smith, K., \& Dhillon, G. (2017). Blockchain for digital crime prevention: The case of health informatics. Paper presented at the Americas Conference on Information Systems (AMCIS), Boston, 2017.

Spieth, P., Schneckenberg, D., \& Ricart, J. E. (2014). Business model innovation-state of the art and future challenges for the field. $R \& D$ Management, 44(3), 237-247.

Struyf, A., Hubert, M., \& Rousseeuw, P. (1997). Clustering in an objectoriented environment. Journal of Statistical Software, 1(4), 1-30.

Subramanian, H. (2018). Decentralized blockchain-based electronic marketplaces. Communications of the ACM, 61(1), 78-84.

Swan, M. (2015). Blockchain: Blueprint for a new economy. Sebastopol: O’Reilly Media, Inc.

Szabo, N. (1997). Formalizing and securing relationships on public networks. First Monday, 2(9).

Tapscott, D., \& Tapscott, A. (2016). The impact of the blockchain goes beyond financial services. Harvard Business Review, 10, 2-5.

Täuscher, K., \& Laudien, S. M. (2017). Uncovering the nature of platform-based business models: An empirical taxonomy. Paper presented at the 50th Hawaii International Conference on System Sciences.

Täuscher, K., \& Laudien, S. M. (2018). Understanding platform business models: A mixed methods study of marketplaces. European Management Journal, 36(3), 319-329.

Teece, D. J. (2010). Business models, business strategy and innovation. Long Range Planning, 43(2-3), 172-194.

Treiblmaier, H. (2018). The impact of the blockchain on the supply chain: A theory-based research framework and a call for action. Supply Chain Management: An International Journal, 23(6), 545-559.

Underwood, S. (2016). Blockchain beyond bitcoin. Communications of the ACM, 59(11), 15-17.

Wang, Y., \& Kogan, A. (2018). Designing confidentiality-preserving blockchain-based transaction processing systems. International Journal of Accounting Information Systems, 30, 1-18.

Webster, J., \& Watson, R. T. (2002). Analyzing the past to prepare for the future: Writing a literature review. MIS Quarterly, 26(2), xiii-xxiii.

Weking, J., Hein, A., Böhm, M., \& Krcmar, H. (2018a). A hierarchical taxonomy of business model patterns. Electronic Markets (in press). 
Weking, J., Stöcker, M., Kowalkiewicz, M., Böhm, M., \& Krcmar, H. (2018b). Archetypes for industry 4.0 business model innovations. Paper presented at the Twenty-fourth Americas Conference on Information Systems (AMCIS 2018), New Orleans, LA, USA.

Weking, J., Böttcher, T., Hermes, S., \& Hein, A. (2019). Does business model matter for startup success? A quantitative analysis. Paper presented at the Twenty-Seventh European Conference on Information Systems (ECIS 2019), Stockholm-Uppsala, Sweden.

Werth, J. C., \& Boeert, P. (2013). Co-investment networks of business angels and the performance of their start-up investments. International Journal of Entrepreneurial Venturing, 5(3), 240-256.

Wirtz, B. W., Pistoia, A., Ullrich, S., \& Göttel, V. (2016). Business models: Origin, development and future research perspectives. Long Range Planning, 49(1), 36-54.

Woodside, J. M., Augustine, F. K., Jr., \& Giberson, W. (2017). Blockchain technology adoption status and strategies. Journal of International TechnologyInformation Management, 26(2), 65-93.

Wörner, D., Von Bomhard, T., Schreier, Y.-P., \& Bilgeri, D. (2016). The Bitcoin ecosystem: Disruption beyond financial services? Paper presented at the Twenty-Fourth European Conference on Information Systems (ECIS), İstanbul, Turkey

Xu, L., Shah, N., Chen, L., Diallo, N., Gao, Z., Lu, Y., et al. (2017). Enabling the sharing economy: Privacy respecting contract based on public blockchain. Paper presented at the ACM workshop on Blockchain, Cryptocurrencies and Contracts, 2017.

Xu, L., Chen, L., Gao, Z., Chang, Y., Iakovou, E., \& Shi, W. (2018). Binding the physical and cyber worlds: A blockchain approach for cargo supply chain security enhancement. Paper presented at the IEEE International Symposium on Technologies for Homeland Security (HST), 2018.

Ying, W., Jia, S., \& Du, W. (2018). Digital enablement of blockchain: Evidence from HNA group. International Journal of Information Management, 39, 1-4.

Yu, Y., \& Perotti, V. (2015). Startup tribes: Social network ties that support success in new firms. Paper presented at the $21 \mathrm{st}$ Americas Conference on Information Systems (AMCIS), Puerto Rico

Zhao, J. L., Fan, S., \& Yan, J. (2016). Overview of business innovations and research opportunities in blockchain and introduction to the special issue. Financial Innovation, 2(1), 1.

Zhu, H., \& Zhou, Z. Z. (2016). Analysis and outlook of applications of blockchain technology to equity crowdfunding in China. Financial innovation, 2(29), 1-11.

Publisher's note Springer Nature remains neutral with regard to jurisdictional claims in published maps and institutional affiliations. 